OPEN ACCESS

Citation: Fabio Bordignon, Luigi Ceccarini (2021) Where has the protest gone? Populist attitudes and electoral flows in Italian political turmoil. Quaderni dell'Osservatorio elettorale - Italian Journal of Electoral Studies 84(2): 41-64. doi: 10.36253/qoe-10768

Received: April 12, 2021

Accepted: October 25, 2021

Published: November 1, 2021

Copyright:@2021 Fabio Bordignon, Luigi Ceccarini. This is an open access, peer-reviewed article published by Firenze University Press (http://www. fupress.com/qoe) and distributed under the terms of the Creative Commons Attribution License, which permits unrestricted use, distribution, and reproduction in any medium, provided the original author and source are credited.

Data Availability Statement: All relevant data are within the paper and its Supporting Information files.

Competing Interests: The Author(s) declare(s) no conflict of interest.

Orcid

FB: 0000-0002-7852-5849

LC: $0000-0002-7204-506 \mathrm{X}$

\section{Where has the protest gone? Populist attitudes and electoral flows in Italian political turmoil}

\author{
FABio BordignoN ${ }^{1}$, LUIGI CECCARINI ${ }^{2, *}$ \\ 1,2 University of Urbino Carlo Bo, Italy \\ ${ }^{\star}$ Corresponding author. Email: luigi.ceccarini@uniurb.it
}

\begin{abstract}
What happens when anti-establishment political actors gain strength, enter institutions, and even become the new establishment? To what extent are their electoral profiles a nd the demands b ehind them n ormalised by the system? Th is ar ticle uses ITANES surveys to investigate voters' reactions to the different paths taken by the three main protagonists of the 2016-2020 Italian populist wave: the M5S, the Lega, and FDI. In particular, it uses panel data to study the evolution of populist attitudes and protest drivers, as well as their connection with electoral flows a nd parties's strategic choices. The most striking change concerns the redefinition of the political outlook of 5 -star voters, who have significantly reduced their populist stances. However, the transformation of the M5S into a government party produced significant outflows of voters who already in 2016 expressed greater resentment towards political elites. These dynamics have largely favoured parties of the populist right - the Lega and then especially FDI - which have preserved or even reinforced their (electoral) profile as antiestablishment parties.
\end{abstract}

Keywords: Italian political system, institutionalisation, populism, anti-establishment parties, electoral behaviour.

\section{INTRODUCTION}

What happens when anti-establishment political actors gain strength, enter institutions, and even become the new establishment? To what extent are their electoral profiles and the demands behind them normalised by the system? The rise of challenger (populist) parties in many established democracies has renewed interest in such questions in recent years. These parties have been able to tap into a widespread democratic malaise which translates into protest voting, challenges mainstream parties, and often rewrites the patterns of party competition. Their success and potential access to government positions have been seen both as a threat to democratic polities and as a way of channelling the discontent with unanswered social demands into the political system.

From Guglielmo Giannini's Fronte dell'Uomo Qualunque (Common Man's Front) over the '40s to Silvio Berlusconi's personal party since the ' 90 s, 
Italy already had a long tradition as a populist laboratory (Tarchi 2015). The last decade, however, has brought renewed attention to the Italian case given the strength and composite nature of its new populist wave (Caiani and Graziano 2016), rewarding different anti-establishment parties at different times. The constitutional referenda of 2016 and 2020 mark two crucial steps in this process, as has occurred in other established democracies (Uleri 2002; Qvortrup 2018). In 2016, the post-ideological M5S (Movimento 5 Stelle - Five-Star Movement) and the right-wing Lega were the main opposition parties and part of the large and heterogeneous coalition opposing the constitutional reform promoted by Prime Minister Matteo Renzi and his PD (Partito Democratico - Democratic Party). They were also the main interpreters of the Italian "populist zeitgeist» (Mudde 2004), which would enable them to 'win' the 2018 general election and give birth to the self-defined 'government of change' (2018-2019).

Four years later, the M5S was the main supporter of a new reform downsizing the parliament by a third. At the same time, it was the main governing party. On the other side, the Lega was the main opposition party. Matteo Salvini's party had left the government, calling for early elections, after its resounding success at the 2019 European election. Meanwhile, another radical right party, Giorgia Meloni's FDI (Fratelli d'Italia - Brothers of Italy), was gaining momentum in the polls.

The different paths of these three parties provide a unique observatory to assess if (and how) voters react to the different roles assumed by challenger parties with respect to the majority-opposition line of division. This article uses panel data to investigate the electoral distribution of populist attitudes and protest drivers in the 2016-2020 timeframe. The longitudinal research design makes it possible to study the evolution of the profiles of these parties' electorates concerning the analysed dimensions, linking them to electoral flows in a highly volatile electoral market.

This approach enables testing whether the access to government positions was accompanied by a (partial) mitigation of protest elements in the political outlook of challenger parties' electorates, or whether it was matched, on the contrary, by an outflow of 'critical voters' who found new challengers ready to channel their resentment. The next section provides the theoretical framework adopted in this article. The third discusses the relevance of the Italian case for the study of these phenomena. The following two sections introduce the research hypotheses (section 4) and the research design (section 5). The next three sections present the results: section 6 briefly reconstructs the electoral evolution of the three challenger parties between the two constitutional referenda and provides the electoral flows to explain such changes; section 7 provides a descriptive account of the signs of social and political malaise in the party electoral profiles between 2016 and 2020; and section 8 links such changes to party flows, using multinomial logit models. The final section summarises the main findings and discusses the main clues for understanding the rapid evolution of the Italian political system.

\section{WHEN ANTI-ESTABLISHMENT ACTORS BECOME THE NEW ESTABLISHMENT}

Different but partially overlapping concepts have been used to describe the recent rise of challenger parties that have contributed to the rapid evolution of party systems in old and new democratic polities. Populism is probably the most recurrent and crosscutting category in today's readings of the transformations of politics at the global level (Meny and Surel 2002; Albertazzi and McDonnell 2007; Diamanti and Lazar 2018). In Mudde's renowned ideational conceptualisation, populism has two main components: people-centrism and antielitism (Mudde 2004). These two dimensions combine themselves and reinforce each other in populists' view. They translate into the idea that people's place in society should be restored through the release of the popular 'general will', freed from the obscure and tentacular influence of different kinds of elites.

People's enemies may assume different 'faces' according to different conceptions of the people - but political oligarchies and mainstream parties are almost always ideal (and privileged) populist targets.

Although significant 'degrees' of populism are increasingly exhibited by different political actors - both old and new parties, both government and opposition populism remains primarily a powerful strategic weapon in the hands of opposition forces.

Populist parties often present themselves as antiestablishment parties, channelling the protest towards political elites originating from a mix of widespread social, cultural, and political malaise affecting contemporary democracies (Inglehart and Norris 2016; Morlino and Raniolo 2017).

A large strand of literature has linked their success to the effects of globalisation, particularly in economic and cultural terms (Angelucci and De Sio 2021, Crouch 2020). Their constituents have been described as the «losers of globalisation» (Kriesi et al. 2006) and of the recurrent crises of the globalised world: from the Great 
Recession of 2008, to the refugee crisis of 2015, to the most recent Covid-19 pandemic. Issues such as economic dissatisfaction and stagnating living standards, identity, and fears generated by migration flows, combined with the role of technology and social media communication in particular (Mounk 2018), have often been identified as major factors fuelling votes in favour of challenger parties. It was in the increasing void between the demos and party democracy (Mair 2013) that these political forces became the ideal electoral outlet for disappointed, disillusioned, 'critical' voters. These social components choose them to give voice to their protest against established political actors and their 'system', considered far away from their own interests and demands.

Populist actors' attacks do not involve only national institutions; they have European institutions and the EU membership itself as ideal targets. In their views, European authorities and the European bureaucracy are considered close to the great powers of the globalised world. For these reasons, the EU is blamed for the consequences of globalisation on (ordinary) citizens' living standards and its failure to tackle the issues related to it. Moreover, European institutions are often seen as a limitation of national democracy, depriving citizens of their right to decide for themselves. For these reasons, populist actors often call for a recovery of national sovereignty through an exit from the EU (or from the eurozone).

The dynamics outlined above open up important questions about the effects of populism on democratic systems and the key mechanism of representation. However, they also open up questions about the effects of the political system on populist actors. When they enter democratic institutions and access government positions, populist parties have the opportunity to translate their ideas into political decisions. They can tackle the social issues that favoured their rise. They can bring their innovative drive into the system, trying to change its rules and formal arrangement. However, they are also influenced by their new position and by the role they assume. The contact with institutions often normalises and institutionalises them.

There is a steadily expanding strand of literature addressing the theme of populists in power (Albertazzi and McDonnell 2016; Rovira Kaltwasser and Taggart 2016). This article will not analyse the changes induced by 'the system' on populist parties in terms of their political message, internal organisation, or communication style. Instead of looking at these dimensions, it will focus on their constituency and their voters' attitudes, studying their evolution given the institutional roles assumed over time. The main aim is to assess if and how access to government roles by challenger parties is accompanied by a redefinition of the populist attitudes of their electoral base. The analysis will focus on a specific country in a specific time window: Italy between 2016 and 2020.

\section{THE ITALIAN BACKGROUND}

Since the early 1990s, Italy has become an extraordinary laboratory for the study of populism (Tarchi 2015; Caiani and Graziano 2016). The advent of Berlusconi and Berlusconi's centre-right has provided scholars with plenty of empirical material to study populism and populism in power. However, the end of Berlusconi's era (Ceccarini, Diamanti and Lazar 2012) and a new political transition have paved the way for the advent of new populist actors, who have largely altered the Italian political scene and its bipolar arrangement (Diamanti and Natale 2014).

In this process, a central role has been played by one political actor in particular: the M5S (Corbetta and Gualmini 2013; Bordignon and Ceccarini 2013; Biorcio and Natale 2018). With its post-ideological (or multi-ideological) approach, the movement party founded by the former comedian Beppe Grillo (2009) has been able to redefine the old centre-right vs centre-left duopoly. Maybe the most interesting feature of Grillo's political creature regards its ability to combine a wide array of different populist messages, solutions, and host ideologies. Nevertheless, the most recent phase has also witnessed the emergence of populist actors with a more ideologically delimited populist profile. Matteo Salvini has been able to transform the old regionalist LN (Lega Nord Northern League) into a radical right, nationalist, and anti-immigration populist party (Passarelli and Tuorto 2018). Giorgia Meloni, a former member of the postfascist AN (Alleanza Nazionale - National Alliance), has been able to bring her FDI - founded in 2013 as a Berlusconi's PDL splinter party - to 'lead' the European Conservatives and Reformist Party. Although representatives of the Lega and FDI participated in centre-right coalition governments in the past, both centre-right parties, as well as the M5S, fiercely opposed all the grand coalition governments that Italy has had since 2011.

In 2016, all three parties were part of the large and composite political front opposing Prime Minister Renzi's constitutional reform in the referendum on 4 December. Renzi himself, as the secretary of the main centre-left party and the head of government, had tried to embody a sort of soft populism, initially obtaining wide support from public opinion (Bordignon 2014; Ventura 2015). Renzi had also tried to assign a populist 
'meaning' to some popular contents of his reform, seeking to transform the vote for it into a personal plebiscite. However, by the end of 2016, his star had largely eclipsed: his government, his party, and his leadership epitomised the establishment itself in a climate of growing social resentment and anti-establishment feelings. The resounding defeat in the referendum would become the prologue to what would happen a year and a half later, in the general election of March 2018.

The incumbent PD and its centre-left coalition suffered another bitter defeat, while the M5S and the Lega were the main winners of the 2018 parliamentary election. The two parties contested the election on different sides of a still tripolar competition. The M5S won almost a third of the vote. Salvini's new Lega achieved the best result in its long history (17\%), establishing itself for the first time as the leading party in the centre-right area.

This result was described as a populist fest, paving the way to the birth of a populist yellow-green ${ }^{1}$ government (Bellucci 2018). After months of political deadlock, the two parties reached an agreement to form a self-defined "government of change», led by the previously unknown jurist Giuseppe Conte (Pasquino 2019). The success of the new populists in power has been explained as the result of a social, cultural, and political malaise connected to different factors: the lingering effects of the economic crisis on the middle- and lowerclass households; the fears produced by international migration and multi-ethnic society; and the widespread dissatisfaction regarding the functioning of state institutions and the conduct of a political class seen as elitist and self-referential (Barisione, Bellucci and Vezzoni 2018; Emanuele and Paparo 2018; Chiaramonte et al. 2018; Bordignon, Ceccarini and Diamanti 2018).

The economy was one of the main themes characterising the 2018 electoral campaign and citizens' priorities (Valbruzzi 2019). The success of the M5S and the southernisation of its 2018 electoral map have been linked to the party's ambitious plan to tackle economic conditions - and poverty in particular - through its «citizenship income» project. Immigration was another theme characterising the campaign and, in particular, a central theme of Salvini's platform. The success of the Lega and its expansion towards central and even southern regions have often been associated with its leader's constant and flamboyant anti-immigration rhetoric, and then with his closed-borders policies as the minister of the interior in the Conte I cabinet.

The European Union and the euro currency have also been important issues, continuously discussed in

${ }^{1}$ Yellow (M5S) and green (Lega) were the traditional colours of the two government parties. the political and public debate in recent times (Bellucci and Conti 2012). Over time, a relevant distinction between pro-/anti-European parties has taken shape (Conti 2014). Eurosceptic positions have been expressed, at different times and with different degrees, by all three populist parties analysed in this article. The Lega has explicitly expressed itself in favour of an Italian exit from the eurozone in the past. The M5S has often maintained an ambiguous position on this point, stating on several occasions that the decision should be up to the citizens through a referendum.

The Conte I cabinet would be in office for just over a year. In fact, in the turbulent summer of 2019, Salvini would leave the government to try to capitalise on the extraordinary result of the European vote (34\%) through early elections. However, his move would lead to the formation of a new yellow-red government supported by the M5S and the PD: the Conte II cabinet.

Thus, when considering the entire 2016-2020 timeframe, the three populist parties at the centre of this work followed different paths. The M5S reached and steadily maintained, since 2018 , the government position. The Lega has been part of a government experience, then (unintentionally) returned to the role of main opposition party. Finally, FDI constantly continued to hold its opposition role.

As section 4 will recall, these different political trajectories were combined with different electoral trends. The constitutional referendum of September 2020, amid the pandemic emergency, closes the observation window. Strongly promoted by the M5S and justified by the (populist) objective of reducing the costs of politics, the reform, which reduces the number of MPs by a third, was approved by $70 \%$ of Italians.

\section{RESEARCH HYPOTHESES}

Given the theoretical and historical framework discussed in the previous sections, and the peculiar empirical setting provided by the Italian case between 2016 and 2020, a series of (partially alternative) hypotheses can be formulated regarding the electoral evolution of Italian challenger parties.

H1. The first theoretical expectation is that access to government positions by challenger parties may contribute to attenuating populist orientations and protest drivers in the electorate. This trend may stem from psychological dynamics related to the relationship between electoral choices and orientation towards state institutions and government actors. However, it may also result from a change in (real or perceived) individual conditions, in 
relation to the social and cultural issues that had oriented the vote choice. Regarding the first point, the change in government actors may contribute to varying the public image of the elites themselves, reduce the distance between citizens and the corridors of power, and foster a greater sense of inclusion for those social components that previously felt excluded from the political game. Regarding the second point, it is possible to speculate that access to the levers of power by (former) challenger parties implies that previously neglected issues have entered the agenda and are effectively translated into implemented public policies, or that citizens have, anyway, the perception that such issues are being considered by decision makers. This general hypothesis will be confirmed if the data allow us to observe the following:

H1a. A dampening of populist and anti-elite sentiments in the electorate at large.

H1b. An attenuation of feelings of social dissatisfaction concerning issues that had previously fuelled the protest against government actors, such as economic performances, immigration, and European integration.

H1c. An increased moderation in the political view of (former) challenger parties' voters.

H2. A partially alternative hypothesis is that access to government does not produce an attenuation of the attitudes of interest, but it rather produces a shift of voters expressing them in the direction of other parties which remain in opposition and become the new interpreters of protest. Whereas some challenger parties gain access to government, other actors may maintain or reinforce their profile as populist and protest parties. By doing so, they have the opportunity to collect citizens' dissatisfaction with new issues or questions that have not been (adequately) addressed yet. They can thus interpret the reactions of critical voters vis-a-vis the transformation of challenger parties into incumbent parties. This hypothesis will be confirmed if the data allow the following conditions to be observed:

$\mathrm{H} 2 \mathrm{a}$. The electorates of (new) opposition parties maintain or reinforce attitudes of distrust towards political elites and deep dissatisfaction with the way old and new social issues are addressed.

H2b. Significant shares of voters from (former) challenger parties who gained access to government positions maintain or reinforce their 'critical profile' and change their vote in favour of (new) challenger parties.

\section{RESEARCH DESIGN}

To test these hypotheses, this study uses ITANES (Italian National Election Studies) panel data, based on national samples of the Italian voting age population, interviewed by the polling firm SWG using the CAWI (computer-assisted web interviewing) method. Using the data sets provided by this project, it was possible to isolate 1412 cases who were interviewed about their political and electoral orientations at four different time points: 1) before and after the 2016 constitutional referendum; 2) after the 2018 general election; 3) after the 2019 European election; and 4) before and after the 2020 constitutional referendum. Data from the 2018 ITANES pre-election survey, collected through a rolling crosssectional design (5528 cases), are also used.

\section{The dependent variable(s)}

The electorates of the main parties were identified using a question on the voting intention for 2016; a question on the voted party for the lower house (proportional part) in the 2018 parliamentary elections; a question on the voted party in the 2019 European elections; and an estimate of voting intentions for $2020 .^{2}$ The longitudinal design of the survey made it possible to reconstruct the overall vote flows in the 2016-2020 time window. This allowed for the creation of three typologies that - for each of the three challenger parties - identify four groups: Loyal party voters (those who were classified as voters of that specific party in both 2016 and 2020), Outgoing party voters (those who were classified as voters of that specific party in 2016 but not in 2020 - they were categorised as voters of another party or as part of the grey area of uncertain voters and potential abstainers), Incoming party voters (those who were classified as voters of that specific party in 2020 but not in 2016), and Other voters (those who were not classified as voters of that specific party both in 2016 and 2020). The sum of these four groups coincides with the entire electorate. These typologies are used as dependent variables in the models presented in section 8 .

\section{The independent variables}

Four sets of indicators were used to isolate the main dimensions of populism and the main protest drivers discussed in the previous sections.

\footnotetext{
${ }^{2}$ These estimates were obtained by combining a propensity to vote (PTV) battery and party identification. This procedure was necessary due to the absence of a specific question on voting intentions in the 2020 questionnaire. Voters were assigned to each electorate according to the highest PTV (on a scale of 0 to 10). Ties (with a PTV higher than 0 ) were then assigned according to the question on party identification. This strategy was preliminarily tested on 2016 data and showed good reliability of the estimates with respect to voting intentions. Moreover, the estimates obtained for 2020 were in line with the voting intention estimates provided, for the same period, by the main polling institutes, with differences of less than one percentage point for all the main parties: results can be provided upon request.
} 
Populism indices. The questionnaire included a sixitem battery suggesting six statements divided according to the two main theoretical components of populism. The first three referred to people-centrism attitudes: «MPs must follow the will of the citizens»; "Citizens, not politicians, should make the most important political decisions»; "I would rather be represented by an ordinary person than a professional politician». The remaining three regarded anti-elite attitudes: "The differences between the politicians and the people are greater than the differences within the people»; «Politicians talk a lot but do little»; «Making compromises in politics actually means selling out one's principles». Respondents were asked whether they "strongly agree», «somewhat agree», «neither agree nor disagree», "somewhat disagree», or «strongly disagree» with each statement. The six variables were recoded and used to compute two additive indices of people-centrism and anti-elitism, ranging from -2 to +2 . Then, these two indices were averaged to compute a general populism index. Unfortunately, the ITANES panel did not include comparable populist measures for 2016 or the 2018 post-electoral survey. For this reason, the descriptive analyses presented in section 7 use data from the ITANES 2018 pre-electoral survey, while the multivariate models presented in section 8 use an alternative (but comparable) anti-elitism index, based on a (partially) different set of statements: «What people call compromise in politics is really just selling out on one's principles»; «Most politicians do not care about the people»; "Most politicians care only about the interests of the rich and powerful».

People's assessment of the economy. Two indices were computed to measure voters' positions on these topics:

- Retrospective assessment of the national economy index. The question asked respondents to evaluate the state of the national economy over the 12 months preceding the interview. The original fivepoint scale ("gotten much better», "gotten somewhat better», "stayed about the same», "gotten somewhat worse», «gotten much worse») was transformed into a synthetic index ranging from -2 to +2 ;

- Retrospective assessment of the household economy index. The question asked respondents to evaluate the state of the household economy over the 12 months preceding the interview. The original fivepoint scale ("gotten much better», "gotten somewhat better», "stayed about the same», "gotten somewhat worse», «gotten much worse») was transformed into a synthetic index ranging from -2 to +2 ;

- Anti-immigration index. The original questions asked respondents to position themselves on a sev- en-point self-anchoring scale. The two extremes represented opposite opinions: «We could easily welcome many more immigrants»; «We receive too many immigrants». For the purposes of comparison, the final index was re-scaled to range from -2 to +2 .

Euro-scepticism index. The questionnaire included two questions regarding the respondents' evaluation of the European membership and European single currency, respectively. Both indicators were based on a three-point scale («a good thing for Italy», «a bad thing for Italy», «neither good nor bad»), and they were used to compute an additive index ranging from -2 to +2 .

\section{The models}

A series of multinomial logit regression models were fitted, considering as dependent variables, for each of the three parties (M5S, Lega, and FDI), the typologies described, with Other voters as a reference category. For each party, nine nested models were fitted, divided into three series:

- The L (lagged variables) series $(1 \mathrm{~L}, 2 \mathrm{~L}$, and $3 \mathrm{~L}$ models) includes as independent variables the 2016 lagged variables (2018 for anti-elitism indices) measuring the main protest drivers and populist attitudes.

- The CS (change scores variables) series (models 1CS, $2 \mathrm{CS}$, and 3CS) includes as independent variables the 2016-2020 change scores (2018-2020 for the anti-elitism indices) for the main protest drivers and populist attitudes.

- The CO (complete) series (1CO, 2CO, and 3CO models) provides the complete models that jointly include lagged variables and change scores for the main protest drivers and populist attitudes.

Within each series, the three models follow this scheme:

- Model 1 (1L, 1CS, and 1CO) includes the corresponding measures of anti-elitism as independent variables.

Model 2 (2L, 2CS, and 2CO) adds to Model 1 the corresponding measures regarding the retrospective assessment of the national economy index, the retrospective assessment of the household economy index, the anti-immigration index, and the Euroscepticism index. The choice of this sequence is linked to the characterisation of these attitudes as protest drivers, according to the theoretical framework adopted in this article.

Model 3 (3L, 3CS, and 3CO) controls Model 2 for the respondents' self-placement on the ideologi- 
cal left-right axis. The original 11-point scale was recoded into six categories: Left (0-2), Centre-left (3-4), Centre (5), Centre-right (6-7), Right (8-10), and Not-placed. This latter category, including people who refuse to place themselves on the traditional ideological axis, was considered as the reference category.

Finally, all models are controlled for the main sociodemographic variables:

- Gender, dichotomous variable (with men as the reference category).

Age, linear (in years).

- Education, categorical variable with three categories: primary (reference category), secondary, and tertiary.

- Region, categorical variable with three areas: North (reference category), Centre (ex-Red Zone), and South and Islands.

\section{2016-2020: THE PROTEST GALAXY IN MOVEMENT}

Taken together, the three anti-establishment parties analysed in this article significantly increased their support in the period between the European elections held in 2014 and the opinion polls conducted in October 2020, immediately after the constitutional referendum. From about three voters out of ten (31\%), these forces ended up attracting the support of more than half of Italian voters $(55 \%)$ in just a few, but vibrant, years.

As shown in Figure 1, the Lega, M5S, and FDI had very different political paths. During the 2014 European elections, Salvini's and Meloni's parties were then still minor, with rather little electoral support: FDI got 3.7\% of valid votes, while the Lega received just over $6 \%$. On the other hand, the M5S achieved a much higher electoral result (21.2\%), although significantly below its vote share in the 2013 general election (25.6\%) (Diamanti, Bordignon and Ceccarini 2013; ITANES 2013). However, this scenario would rapidly change over the following few years. A fluctuating trend characterised the voting intentions for the Lega and the M5S. Meanwhile, Meloni's party, after a phase of slight growth, showed a very sharp increase.

The M5S, which joined other parties on the 'No' front in the 2016 constitutional referendum (Ceccarini and Bordignon 2017), showed a leap forward of more than 10 percentage points between the 2014 European elections and June 2016 (when its potential votes reached $32.3 \%$ ). Then, it stabilized at around $28 \%$ until the 2018 general election, when it reached its highest level of pop- ular approval: 32.7\%. Nevertheless, after this 'movement party' took over government responsibilities, a considerable loss of votes started to shape its electoral path. Following the more recent European elections, held in 2019, the M5S settled around $16-18 \%$, just over half of the highest level of support ever achieved. This translated into a complex phase regarding its internal organisation and leadership.

The Lega's trend parallels that of the M5S until the 2018 general election (even though at a lower level). However, after that, things significantly shifted, as the M5S began to lose its votes, whereas the Lega started to gain increasing approval ratings. The Lega's secretary, Salvini, had assumed leadership after the party's defeat in the 2013 general election. He rapidly became the architect of the party's success and profound shift: from a 'territorial' party, the old LN turned into Salvini's national Lega.

After having signed the "Contract for the government of change» (May 2018) with the 5-Star leader, Di Maio, and having served as minister of the interior in the Conte I cabinet, Salvini decided to leave the yellowgreen alliance in August 2019, after the unprecedented result obtained at that year's European election. Following that, however, the Lega began to lose citizens' support. It decreased to $23 \%$ within a single year (October 2020). This dynamic seemed to favour the other rightwing party, FDI, which did not take up any office in the Italian government over the considered timeframe.

Considering the electoral flows between 2016 and 2020, relevant dynamics can be detected (Table 1). The most notable of these relates to the votes outflowing from the M5S. The portion of the 'Loyal' voters between 2016 and 2020 was around 32\%, a very low number when compared with the loyalty shown by the electoral bases of the Lega and FDI - respectively $62 \%$ and $70 \%$. Confirming the multi-ideological nature of this party, outflows followed multiple directions during the analysed timeframe - just like inflows between 2012 and 2013 (Bordignon and Ceccarini 2013). Particularly significant during this phase, however, appeared to be the component of former M5S voters - 31\% - heading towards centre-right. A very slight minority (4\%) chose FI. However, Berlusconi's party cannot be considered a 'pure' anti-establishment political force - not any longer, at least. Many of them switched to FDI (11\%) and, in particular, to the Lega (16\%). The 'elective affinities' shared by a relevant component of the electoral base of the M5S with Salvini's Lega (Bordignon and Ceccarini 2016) seem to have translated into concrete vote flows. The "government of change», formed together by the two anti-establishment parties, seems to have benefitted 


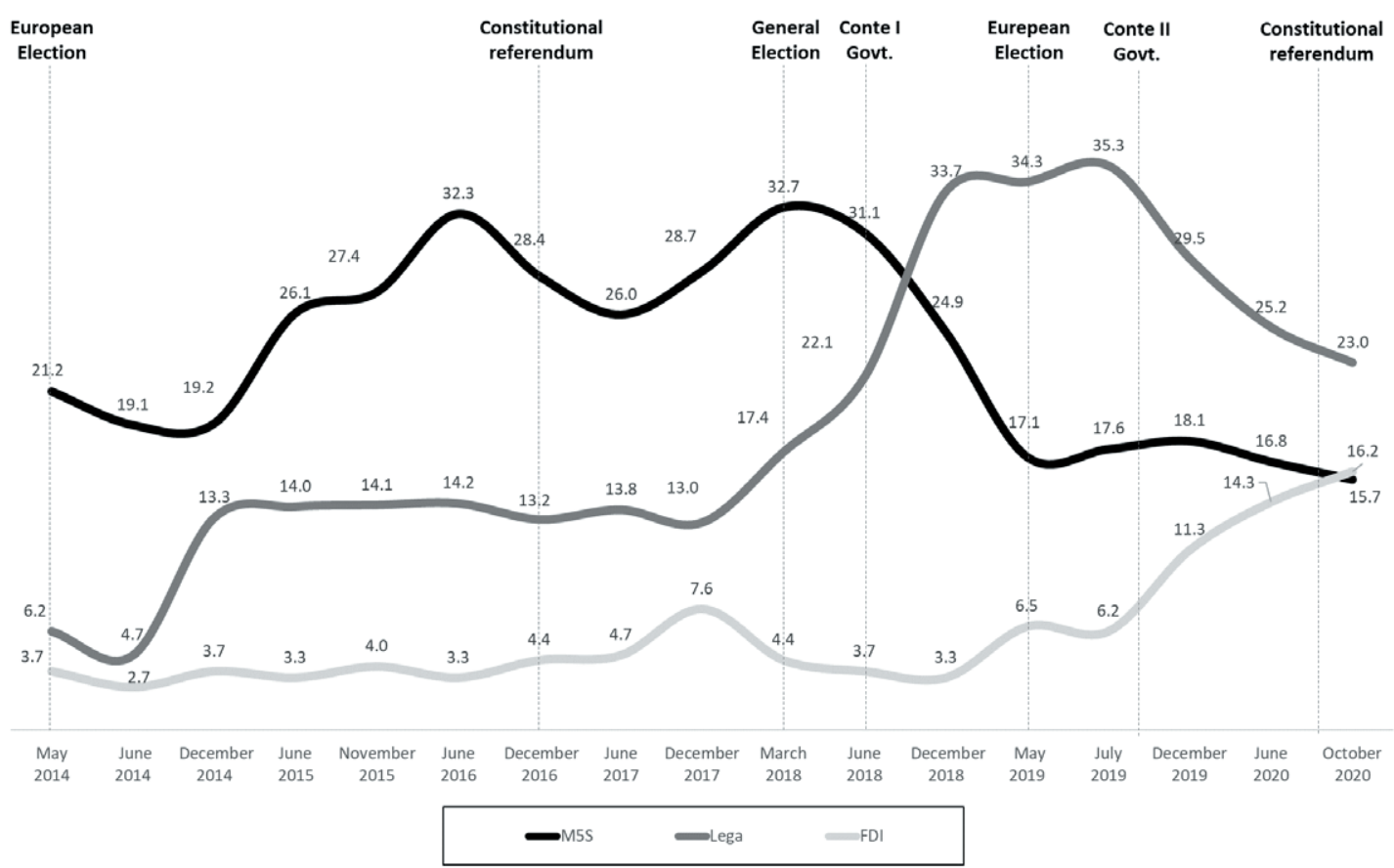

Figure 1. Electoral trends for M5S, FDI and Lega: 2016-2020 (\%). Source: Demos \& Pi surveys.

first and foremost Salvini's Lega at the expense of the M5S.

As for the electoral flows within the two right-wing parties, the results also show that the Lega and FDI have jointly been able to drain a significant component of FI voters: more than $40 \%$. However, Meloni's party has also been able to attract a significant component of the Lega's voters, and this trend is confirmed if we zoom in on 2019-2020 flows (Table 2): as much as $23 \%$ of the Lega's (large) 2019 electorate switched to FDI in 2020.

\section{TRACING POLITICAL AND SOCIAL MALAISE IN THE EVOLUTION OF PARTY PROFILES}

Given the political and electoral trajectories of the three challenger parties analysed in this article, it will be interesting to understand how these different routes, institutional roles, and related political communication contents reflected on the orientations of their electoral bases and of the Italian public opinion at large. This section of the article will descriptively analyse the evolution of populist orientations and protest drivers in the Italian electorate in general and among the voters of the five main parties. The next section uses the multinomial logit models introduced earlier to test the relationship between these orientations, their evolution, and vote flows in the 2016-2020 timeframe.

\section{Populism: people-centrism and anti-elitism}

When comparing voters' orientations in 2020 with the pre-electoral scenario in 2018 , the most striking change concerns the general decrease of all the populist measures considered in this study. This is apparent both when considering the trend of the basic indicators (Table A.1 in the Appendix) and when looking at the synthetic indices provided by Figure 2 . The overall populism index drops from 0.88 to 0.58 . The anti-elitism index declines from 0.95 to 0.74 and the people-centrism index from 0.81 to 0.42 .

The electorates of the three challenger parties confirm the expected profile, generally displaying aboveaverage figures. These results clearly distinguish them from the voters in general and the PD electoral base in particular. FI voters show, at least in some cases, figures similar to those of the challenger parties. However, their paths were very different during the 2016-2020 timeframe. In fact, the most surprising drops regard the M5S on all indices (Figure 2). As for the people-centrism index, the M5S experienced the most significant decrease, while remaining above average. In the case of the anti-elitism index, the party even fell above the average, whereas the Lega and FDI maintained values above those of the entire electorate and, in particular, not far from those recorded on the eve of the previous general elections. 
Table 1. Estimate of electoral flows 2016-2020 (\%).

\begin{tabular}{|c|c|c|c|c|c|c|c|c|c|}
\hline \multirow{2}{*}{$\begin{array}{l}2020 \text { voting intentions } \\
\text { estimate }\end{array}$} & \multicolumn{9}{|c|}{2016 voting intentions } \\
\hline & $\begin{array}{l}\text { Sinistra } \\
\text { Italiana }\end{array}$ & $\mathrm{PD}$ & M5S & FI & Lega & FDI & Other & $\begin{array}{l}\text { Abst. / NR } \\
\text { / DK }\end{array}$ & ALL \\
\hline $\mathrm{LeU}$ & 26 & 3 & 3 & & & & 3 & 3 & 3 \\
\hline $\mathrm{PD}$ & 31 & 55 & 9 & 3 & & 5 & 16 & 12 & 17 \\
\hline +Europa & 2 & 3 & 1 & & & & 6 & 4 & 2 \\
\hline M5S & 3 & 5 & 32 & 5 & 1 & & 9 & 9 & 12 \\
\hline FI & & & 4 & 37 & 3 & & 1 & 4 & 6 \\
\hline Lega & 2 & 8 & 16 & 19 & 62 & 4 & 9 & 11 & 17 \\
\hline FDI & 1 & 3 & 11 & 23 & 22 & 70 & 15 & 10 & 13 \\
\hline IV & 1 & 6 & 1 & 3 & 2 & & 1 & 2 & 2 \\
\hline Azione & & 3 & 1 & 1 & 1 & & 2 & 2 & 2 \\
\hline Other/not predicted & 34 & 15 & 21 & 9 & 9 & 21 & 38 & 44 & 27 \\
\hline TOTAL & 100 & 100 & 100 & 100 & 100 & 100 & 100 & 100 & 100 \\
\hline n. cases & 72 & 272 & 338 & 92 & 142 & 44 & 42 & 410 & 1412 \\
\hline
\end{tabular}

Source: ITANES panel surveys 2016-2020 (n. cases 1412).

Table 2. Estimate of electoral flows 2019-2020 (\%).

\begin{tabular}{|c|c|c|c|c|c|c|c|c|c|c|}
\hline \multirow{2}{*}{$\begin{array}{l}2020 \text { voting intentions } \\
\text { estimate }\end{array}$} & \multicolumn{10}{|c|}{2019 voting intentions } \\
\hline & Oth. Left & $\mathrm{PD}$ & $+\mathrm{Eu}$ & M5S & FI & Lega & FDI & Other & $\begin{array}{c}\text { Abst. / NR } \\
\text { / DK }\end{array}$ & ALL \\
\hline$\overline{\mathrm{LeU}}$ & 32 & 7 & 4 & 1 & & & & & 2 & 3 \\
\hline $\mathrm{PD}$ & 21 & 64 & 19 & 6 & 3 & 2 & & 9 & 14 & 17 \\
\hline +Europa & 4 & 1 & 33 & 1 & 1 & 1 & & 12 & 2 & 2 \\
\hline M5S & 9 & 5 & 2 & 54 & 2 & 3 & 2 & 9 & 11 & 12 \\
\hline FI & & & 1 & 7 & 49 & 3 & & & 4 & 6 \\
\hline Lega & 1 & 2 & & 5 & 6 & 57 & 6 & 7 & 8 & 17 \\
\hline FDI & 2 & & 6 & 5 & 22 & 23 & 71 & 8 & 9 & 13 \\
\hline IV & 6 & 5 & 7 & 3 & & 2 & 5 & & 1 & 2 \\
\hline Azione & 2 & 3 & 11 & 1 & 5 & & 2 & & 1 & 2 \\
\hline Other/not predicted & 22 & 13 & 16 & 17 & 13 & 10 & 14 & 55 & 48 & 27 \\
\hline TOTAL & 100 & 100 & 100 & 100 & 100 & 100 & 100 & 100 & 100 & 100 \\
\hline n. cases & 78 & 314 & 48 & 222 & 72 & 282 & 62 & 29 & 305 & 1412 \\
\hline
\end{tabular}

Source: ITANES panel surveys 2016-2020 (n. cases 1412).

\section{Economy assessment and protest voting}

The economic landscape also seems to have changed radically when observed through the lenses of voters' assessments at the beginning and at the end of the observation period. In the autumn of 2020, voters expressed a significantly worse (retrospective) opinion on the state of the national economy than in 2016: the index dropped from -0.54 to -1.14 . It should be noted, however, that this largely reflects the effects of the Covid-19 pandemic. It should also be stressed that the evalu- ation of the economic decline was less negative when referring to the household economy: the corresponding index dropped from -0.39 to -0.46 .

Again, there are significant differences in the evolution of the electorates of the three challenger parties, particularly regarding their assessments of the national economy. Whereas in 2016 the most critical evaluations were those expressed by the electorate of the Lega and the M5S, in 2020, the latter scored the highest value among the main parties and in any case above the general average. In other words, the 2020 electorate of M5S, 

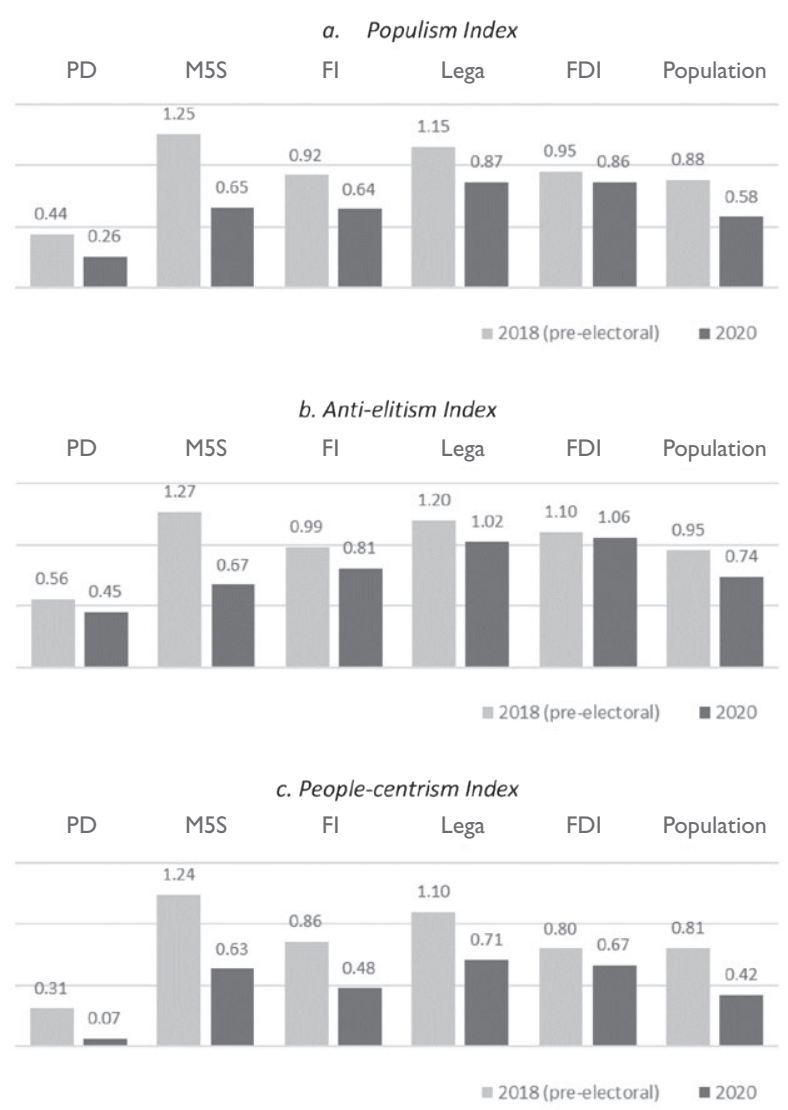

Figure 2. Populism indices. Source: ITANES panel surveys 20162020 (n. cases 1412).

while observing a deteriorating picture and scoring a lower figure than in 2016, was the one that registered a greater resilience of the Italian economy. It should also be noted that the M5S was even the party for which the index of retrospective assessment of the household economy improved the most. In contrast, centre-right parties - the Lega and FDI, again together with FI - displayed the lowest values on both indices in 2020. Even in the frame of a new phase of economic uncertainty, access to government and the possibility of implementing the policies contained in the party's programme seemed to have radically altered the opinions expressed by those who (in different moments) voted for the M5S.

\section{Xenophobic attitudes}

In contrast to the attitudes analysed so far, the antiimmigration index reveals great stability in xenophobic attitudes over the four years considered. The overall figure remained around 0.80 , with a slightly lower value in 2020. The distribution among the main electorates also confirms the traditional ideological connotation of
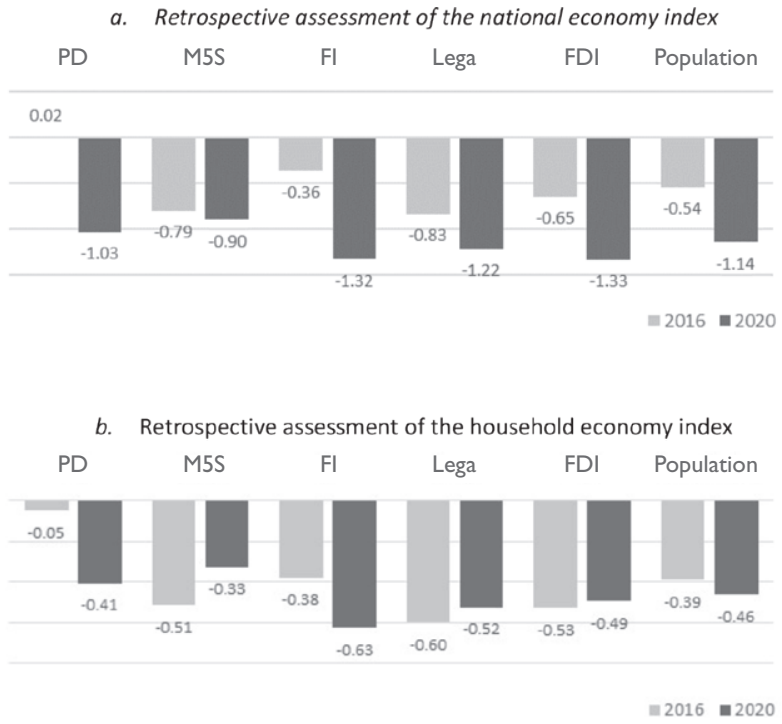

Figure 3. Evaluation of the economy Indices. Source: ITANES panel surveys 2016-2020 (n. cases 1412).

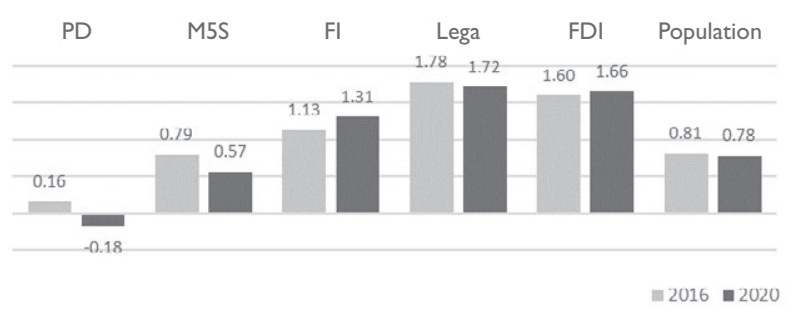

Figure 4. Anti-immigration index. Source: ITANES panel surveys 2016-2020 (n. cases 1412).

these attitudes, especially high among voters of centreright parties compared with those of the centre-left. In particular, the highest values are those collected among the Lega and FDI voters. The index remained around the average for the M5S, confirming the composite nature of its electorate, which translates into an electoral base with different - sometimes divergent - views. It is, however, important to underline that, for the M5S voters, the value of the index in 2020 fell below the general average. This means that the attitudes expressed by the party's electoral constituency have become more moderate on this point.

\section{Europe: the EU and the euro}

The Euro-scepticism index reported in Figure 5 clearly displays how anti-European attitudes generally mitigated between 2016 and 2020, decreasing from - 0.11 to -0.38 . This change can be read, in turn, as an effect 


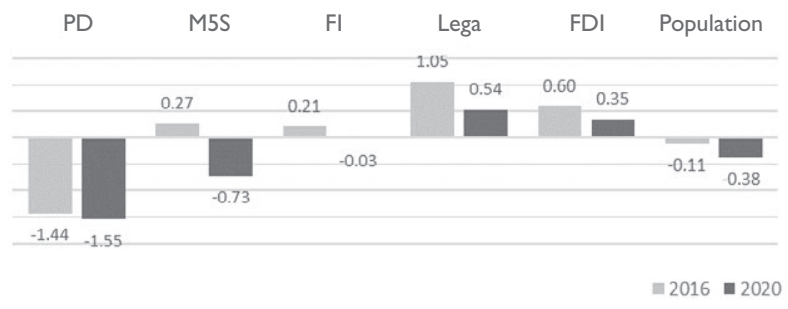

Figure 5. Euroscepticism Index. Source: ITANES panel surveys 2016-2020 (n. cases 1412).

of the pandemic emergency and the role assumed by the $\mathrm{EU}$ as a provider of aid and resources to the countries (including Italy) under greatest strain.

On the centre-left side of the political spectrum, the PD confirmed - through the attitudes expressed by its electorate - its support for the EU. However, Euro-scepticism remained quite high among the Lega's supporters - although it decreased from 1.05 to 0.54 - and FDI's voters - decreasing from 0.60 to 0.35 . Nevertheless, the most striking change regards, once again, the attitudes expressed by M5S voters, which changed direction and moved towards a higher degree of European openness. Their index dropped from 0.27 to -0.73 . This change can be read as a potential effect of the cabinet position assumed by the party during the analysed timeframe.

Summarizing the findings presented in this section, ITANES data enabled a reconstruction of the evolution and distribution of populist attitudes and protest drivers during the turbulent 2016-2020 political phase. The findings indicate the change that occurred within the M5S electoral base. Those voters seem to confirm, in their attitudes, the 'normalisation' of the party process already highlighted by other studies (Tronconi 2018). Considering the dimensions analysed in this study, the M5S electorate was closer to those of other anti-establishment parties in 2016. After about a couple of years in office, the 'anti' element, widely shared among the party voters in the months leading up to the general election, seemed to have largely depleted.

However, regarding both the electorate in general and the party voters, the analyses conducted so far could only provide 'static pictures', taken at the beginning and end of the timeframe: in 2016-2018 and 2020. Yet, in light of what emerged in section 6, we know that these components of the electorate strongly changed in size and internal composition during the four years considered. The multivariate analyses presented in the next section will provide a more dynamic picture by linking the indices used in this section with vote flows.

\section{POPULIST ATTITUDES, PROTEST DRIVERS, AND VOTERS' FLOWS}

The multinomial logit models presented in this section follow the scheme presented in section 5, using the three typologies related to the 2016-2020 vote flows of the three challenger parties as dependent variables. The interpretation of the results of these models is always complex, as it involves fitting multiple equations, the parameters of which must be read considering the reference categories of both the dependent variable and the independent variables (when these latter are categorical). The parameters $b$ can be transformed into $\exp (b)$ and interpreted as relative risk ratios (RRRs): for the models presented in this paper, this would be the 'relative risk' - the equivalent of odds ratios in binary logit models of falling into one of the three identified groups (Loyals, Outgoing, or Incoming) for each party electorate (M5S, Lega, and FDI) over the reference category (consisting of all the other voters), for a given value of one independent variable relative to its reference category - or for a one-unit increase, in the case of continuous predictors holding all other variables constant.

In this instance, however, it was chosen to identify relevant relationships focusing on the sign and significance of the $b$ parameters - reported in Tables A.2-10 in the Appendix - and to make the interpretation easier through the heatplots presented in Figures 6-8. Using the full model (3CO), the probabilities of belonging to each class of the dependent variable (Loyals, Outgoing, Incoming, excluding the reference category) were estimated at different combinations of the independent variables, at the initial (2016-2018) and final (2020) moments of the timeframe. ${ }^{3}$ Then, the difference between the above probability and the overall population mean was calculated. These differences were then represented using heatplots. ${ }^{4}$ Colours shading to black highlight the most significant positive variations, in terms of percentage points. Colours shading to white, on the other hand, signal negative variations.

Because all the (original ${ }^{5}$ ) indices presented in this article have a scale ranging from -2 to +2 , the resulting heatplots are 4 by 4 planes. These planes can be seen as 'maps', and the patterns identified on them can be read as follows:

- The (generally) homogeneous grey indicates the absence of relevant relationships between the varia-

\footnotetext{
${ }^{3}$ Estimated probabilities were obtained as average response using Stata's Margins function.

${ }^{4}$ Jann, B. (2019). heatplot: Stata module to create heat plots and hexagon plots. Available from http://ideas.repec.org/c/boc/bocode/s458598. html.

${ }^{5}$ The change scores range from -4 to +4 .
} 
ble in question or its change over time and the probability of belonging to the group of voters.

- Patterns developing on the North-South axis $(\mathrm{N} \rightarrow \mathrm{S}$ or $S \rightarrow \mathrm{N}$ : quadrant I-II vs quadrant III-IV) or on the East-West axis $(\mathrm{E} \rightarrow \mathrm{W}$ or $\mathrm{W} \rightarrow \mathrm{E}$ : quadrant II-III vs quadrant I-IV) indicate significant relationships with the variable in question at the beginning or end of the timeframe.

- Patterns developing on the South West-North East diagonal ( $\mathrm{SW} \rightarrow \mathrm{NE}$ or $\mathrm{NE} \rightarrow \mathrm{SW}$ : quadrant I vs quadrant III) indicate relationships with the variable in question that are confirmed over the time period considered.

- In the same fashion, patterns developing on the North West-South East diagonal (NW $\rightarrow \mathrm{SE}$ or $\mathrm{SE} \rightarrow \mathrm{NW}$ : quadrant II vs quadrant IV) signal relationships between (positive or negative) variations of the variable in question and the probability of belonging to the analysed group of voters.

These are the main results suggested, for the three parties, by the joint analysis of the regression parameters and the heatplots.

\section{The Five-Star Movement}

Loyals. First, it is important to stress that the sequence of nested models reveals no significant relationship between the 'relative risk' of being a loyal M5S voter (over the 2016-2020 period) and anti-elitist feelings. However, the likelihood of belonging to this group is significantly associated with other protest drivers. It increases among people who, at the beginning of the time interval, formulated a negative (retrospective) assessment of the state of the national economy but changed their evaluation over the four years considered - or at least perceived more resilience on this dimension - recalling that the overall index revealed a marked deterioration in the overall sample. In fact, the heatplot displays both a $\mathrm{N} \rightarrow \mathrm{S}$ and a $\mathrm{NW} \rightarrow \mathrm{SE}$ pattern, although the parameter measuring the impact of change is not significant for this predictor when controlling for its starting level (in Model 3CO). However, a remarkable change characterises their view of the EU: the probability of falling into this component of the electorate increases as a function of improvements in the assessments of European institutions and reaches its highest level among people (on the 'South-Eastern' corner of the plot) who have reversed their judgement.

Outgoing. Anti-elitism is, on the contrary, a key element characterising vote outflows from the M5S. The 'relative risk' of belonging to this group of voters (over the reference category) increases especially among those who, already in 2018, scored high on the anti-elitism index and maintained or strengthened this attitude over the following years: this is confirmed both by the sequence of models constructed and by the diagonal pattern $(\mathrm{SW} \rightarrow \mathrm{NE})$ of the heatplot. Euro-scepticism is another factor that increases the probability of falling into the group of those who quit the M5S. In this case, the $\mathrm{SW} \rightarrow \mathrm{NE}$ pattern of the heatplot is complemented by a $\mathrm{N} \rightarrow \mathrm{S}$ pattern, which underlines the importance of critical feelings towards European institutions in 2016. As in the case of loyal M5S voters, outgoing flows are also favoured by critical assessments of the national economic performance, but not with its change over the four-year period analysed. Finally, there is a negative relationship with xenophobic attitudes, which, however, disappears after controlling for ideological selfplacement. This reflects two elements: on the one hand, the well-known ideological heterogeneity of the M5S electoral base and consequently the diverse opinions on divisive issues in the political debate; on the other hand, it underlines the relevance of other evaluations, as described above, that led to leaving this political force.

Incoming. The analyses do not reveal any significant relationship between the 'relative risk' of being an M5S incoming voter and anti-elitism, even when the corresponding indices are controlled exclusively for sociodemographic variables. Two attributes seem to increase (significantly) the likelihood of falling into the group of M5S incoming voters: a (retrospective) positive assessment of the national economy and, in general, a low degree of Euro-scepticism. The heatplot also seems to disclose an association with high but decreasing levels of xenophobia, even though this relationship is not statistically significant according to the multinomial logit models.

\section{The Lega}

Loyals. Consistent with the themes that have most characterised the party's political battles in recent times, the likelihood of a stable vote for the Lega increases especially among those who show high levels of xenophobia and Euro-scepticism. For this last factor, the relationship with the increase in the 2016-2020 period is also significant. Although a certain (positive) relationship emerges with both economic satisfaction and antielite attitudes, it tends to disappear, or becomes statistically not significant, in the final model (3CO).

Outgoing. Although at lower levels, even in the case of outgoing Lega voters, there is an association with closed attitudes towards immigration and criticism of the EU, particularly when these were expressed at the 
Loyal M5S voters

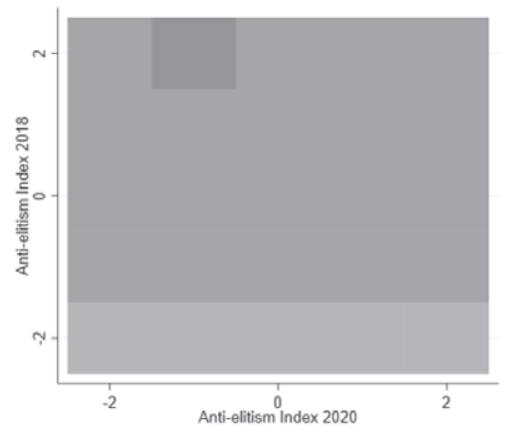

Evaluation of National Economy Index 2016-2020
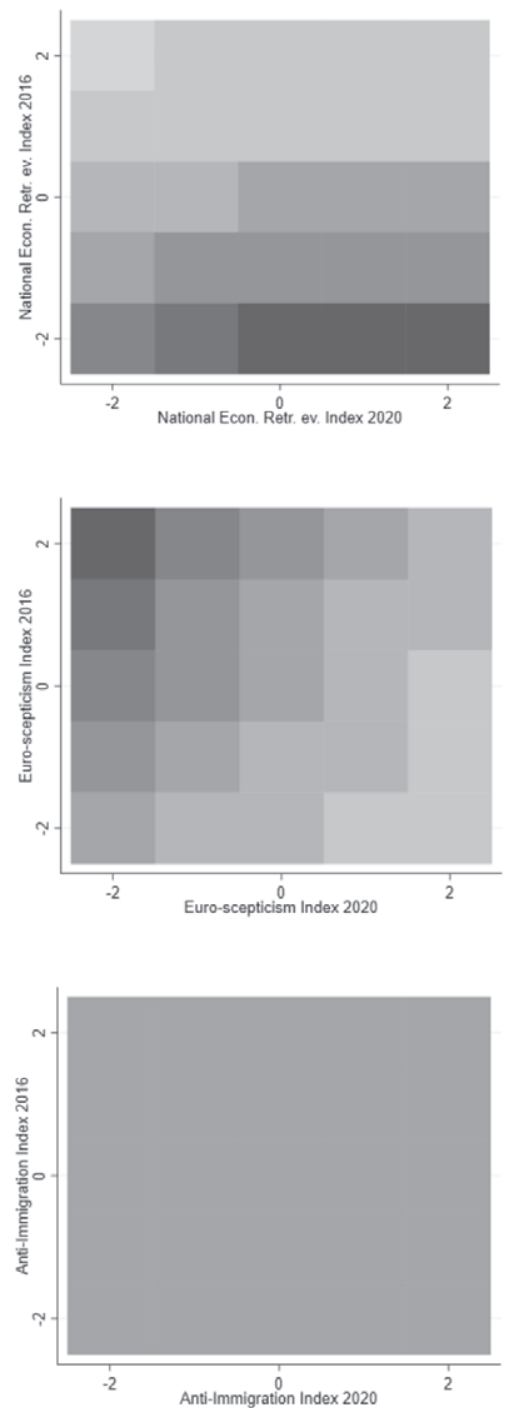

Incoming M5S voters
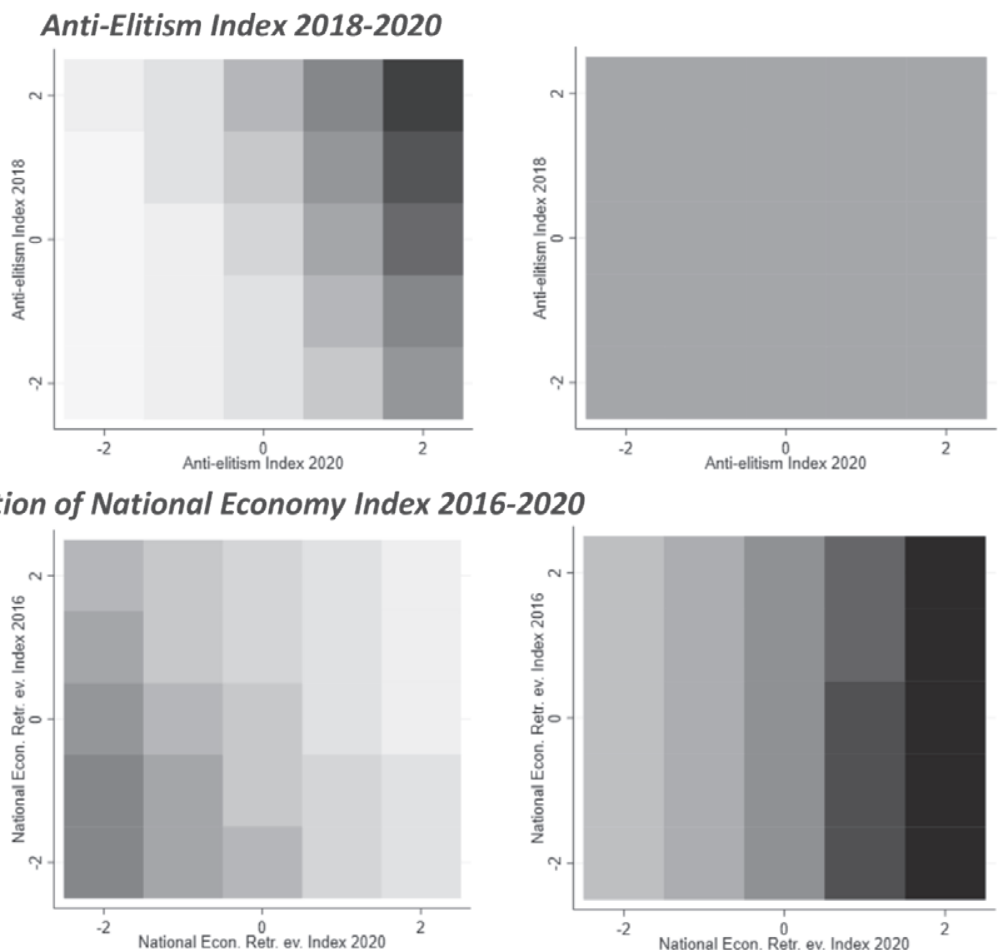

Euro-Scepticism Index 2016-2020
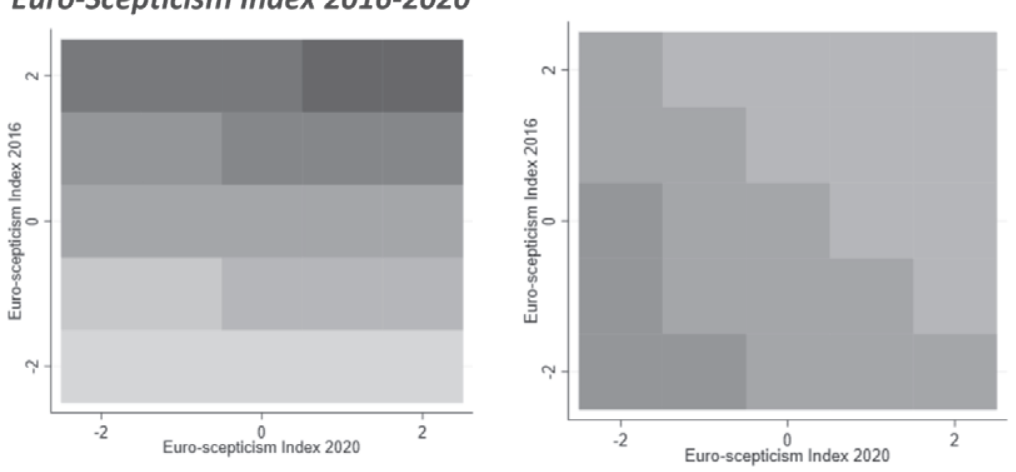

Anti-Immigration Index 2016-2020
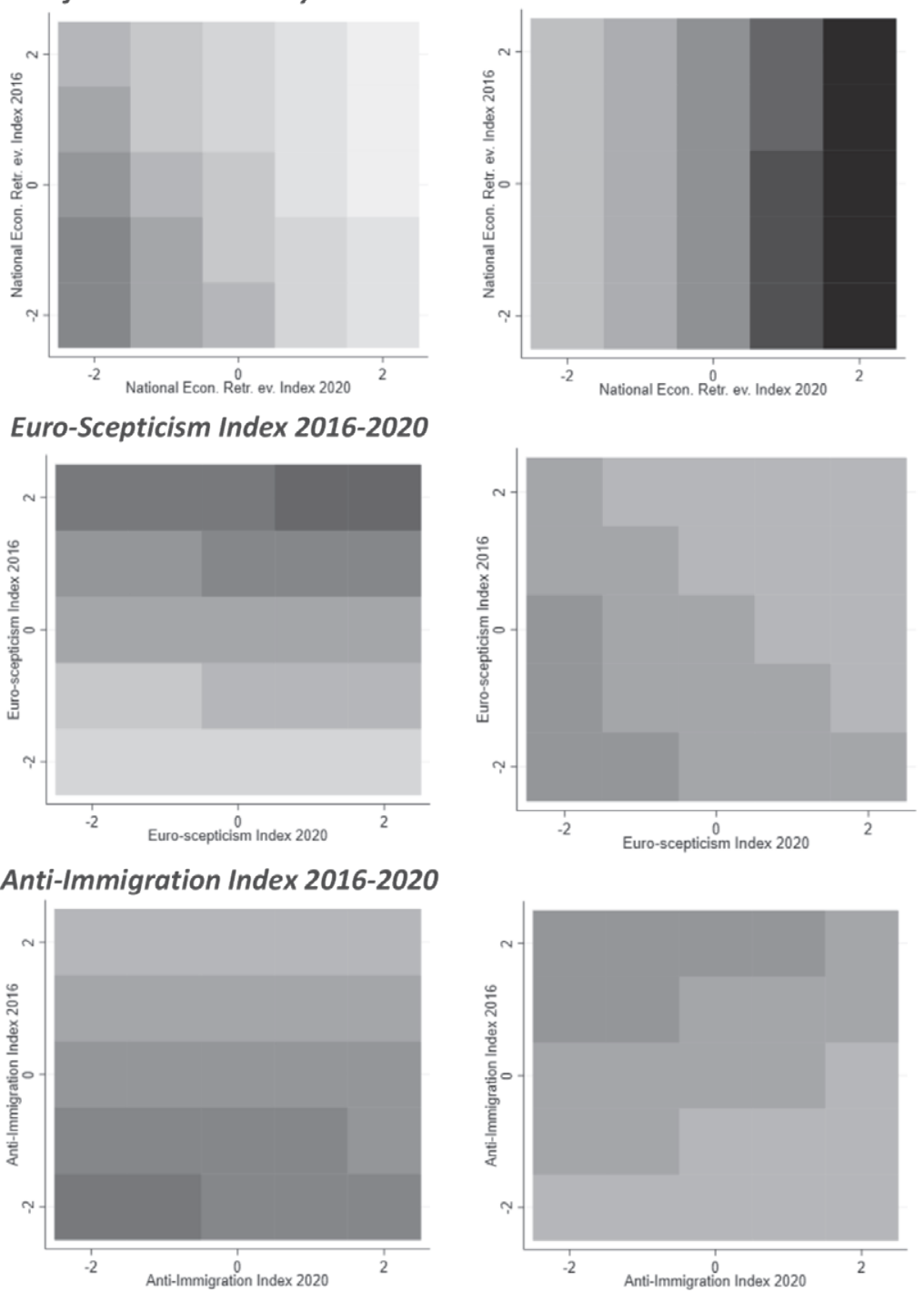

Legend

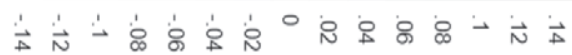

Figure 6. Differences between average probabilities of group membership (estimated through Model 3CO) and population means, at different levels of key predictors at different times - Five Star Movement. Source: ITANES panel surveys 2016-2020 (n. cases 1412). 
Loyal Lega voters

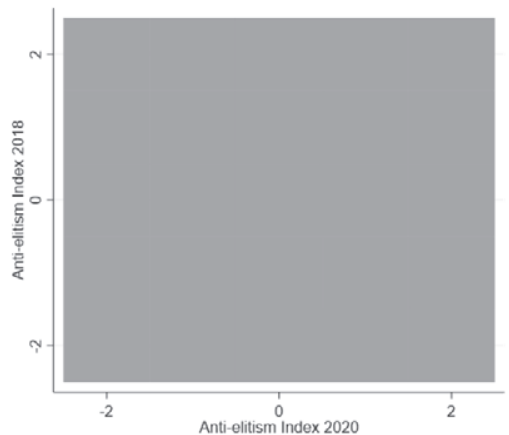

Evaluation of National Economy Index 2016-2020
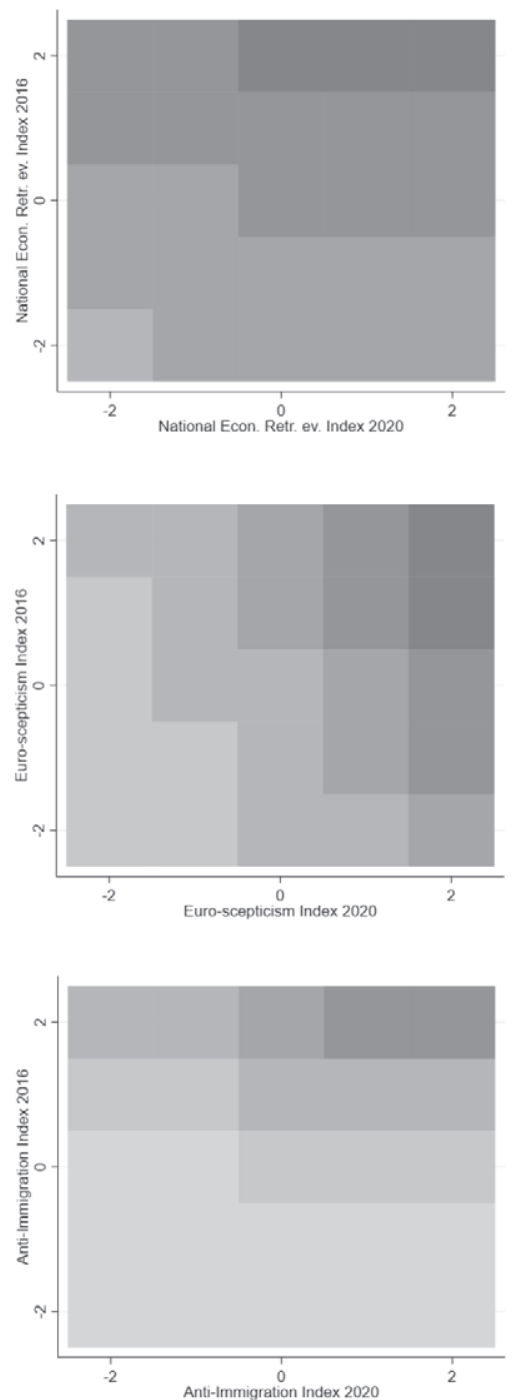

Outgoing Lega voters

Anti-Elitism Index 2018-2020
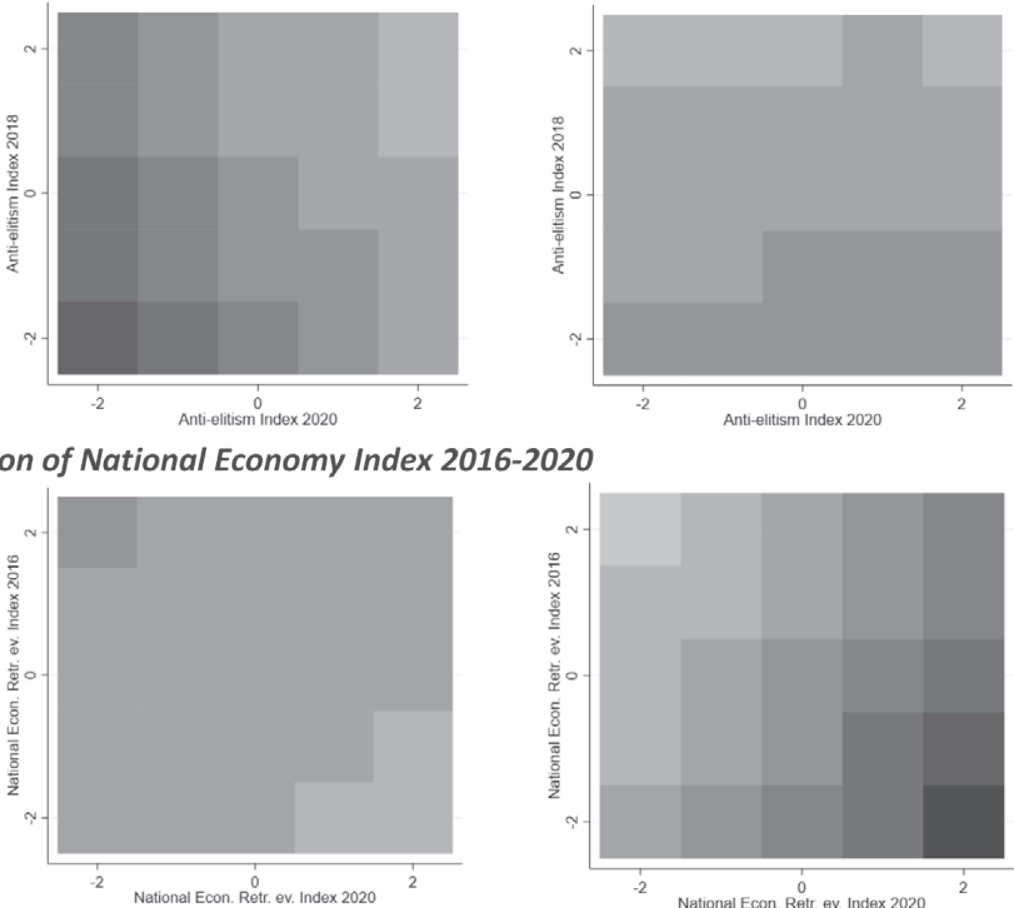

Euro-Scepticism Index 2016-2020
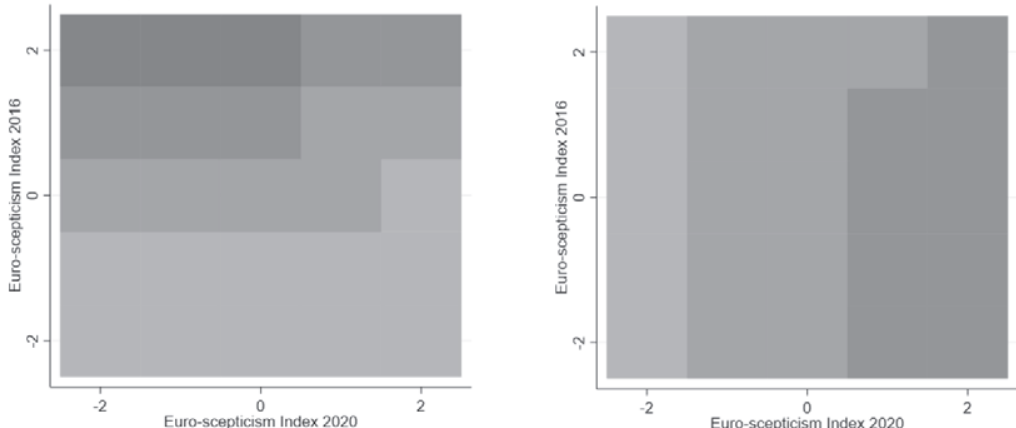

Anti-Immigration Index 2016-2020
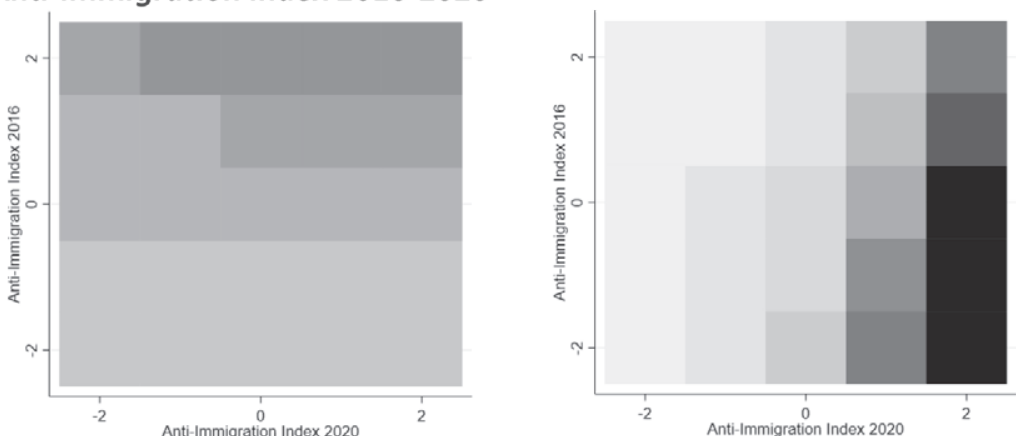

Legend

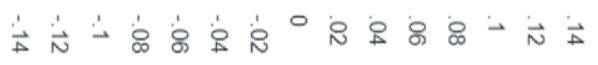

Figure 7. Differences between average probabilities of group membership (estimated through Model 3CO) and population means, at different levels of key predictors at different times - Lega. Source: ITANES panel surveys 2016-2020 (n. cases 1412). 
beginning of the observation period. Interestingly, the 'relative risk' of falling into this group (over the reference category) displays an inverse relationship with antielitism: the likelihood of falling into the group of voters who left the Lega increases - other variables being equal - among those who show a lower and decreasing degree of anti-elitism. This suggests that a less critical judgement of the political establishment is an element that pushes (ex-)Lega voters to no longer identify with this party and the narrative proposed by its leader, and then to move towards other political forces.

Incoming. As suggested by the $\mathrm{NW} \rightarrow \mathrm{SE}$ pattern of the heatplot, the probability of being an incoming voter of Salvini's party increases especially among those who, in 2020, developed strong (and growing) feelings of apprehension about migration. Although the sequence of models reveals some relationship with (growing) antielite sentiments and Euro-scepticism, in the final model, the effect of these factors tends to be overshadowed by the attitudes towards immigration. Finally, the diagonal $\mathrm{NW} \rightarrow \mathrm{SE}$ pattern of the heatplot reveals an association with improving judgements about the state of the national economy: this is confirmed by the corresponding parameters of the models in the CS series, although their significance disappears in the complete series (CO).

\section{Fratelli d'Italia}

In the case of FDI, outgoing voters were aggregated to the reference category, as their sub-sample was too small.

Loyals. Loyal voting for FDI is weakly associated with anti-elitism only in Model 1CO, but this relationship is not significant when the anti-immigration and Euroscepticism indices enter the model. Both attitudes are positively associated with the likelihood of a (stable) vote for FDI, but they lose their significance after controlling for ideological political self-placement, which in the case of FDI loyals has a strong right-wing connotation. The latter result is consistent with the legacy of traditional rightwing, nationalist parties from which FDI descends.

Incoming. On the other hand, there seems to be a closer relationship between anti-elitism (and its growth over the 2016-2020 period) and the incoming vote for FDI (Model 1L, 1CS, and CO). Again, however, these predictors are not significant when controlling for the other variables, in particular anti-immigration attitudes, whose magnitude increases the probability of voting for Meloni's party. Finally, the heatplot shows a weak relationship with critical evaluations of the national economy, which, however, do not emerge as significant in the multivariate models.

\section{CONCLUSIONS}

In the hectic phase between the two recent constitutional referenda (2016-2020), Italy has witnessed profound changes in the configuration of its political system. The elements of protest that fuelled the populist wave have also been largely reshaped. Some of its interpreters have had stable access to government roles since 2018. Others have remained in (or returned to) opposition, proposing themselves as new catalysts for protest linked to persistent and new social issues. The outbreak of the pandemic has changed citizens' perspective on the role of the state and European institutions, ${ }^{6}$ but it has also opened up new issues, which, starting from the health emergency, have already 'infected' other areas of social life - the economy in particular.

ITANES surveys were used in this article to investigate voters' reactions to the different paths taken by the protest actors, focusing on the three political forces that have most proposed themselves as protagonists of the Italian populist zeitgeist: the M5S, the Lega, and FDI. In particular, to study the evolution of voters' populist attitudes and protest drivers, and their connection with electoral flows and parties' strategic choices, panel data were used. The results, although conditioned by some methodological limitations, enable provision of at least partial answers to the research questions at the heart of this work. The main empirical evidence provided by the analyses can be summarised as follows.

1. Both of the main (alternative) hypotheses formulated in section 4 are at least partially confirmed, although providing a more nuanced picture. The access to government by populist parties - the M5S and, in the initial phase, the Lega - has certainly contributed to softening populist orientations in the Italian electorate. All indices of populism used in this study indicate a sizable reduction over the four years of observation (H1a). This shift also coincided with the emergence of a more favourable approach with regard to European institutions. However, Hypothesis H1b is only partially confirmed: sentiments of social discontent related to key issues such as immigration and the economy have certainly not waned. In fact, dissatisfaction with the state of the national economy - and, to a lesser extent, with the household economy - was significantly higher at the end of 2020 than four years earlier. The framework in which these changes have taken place should not be underestimated. In fact, the consequences of Covid-19 represent an intervening variable that inevitably conditioned the dynamics studied in this work. In particular, the growth

\footnotetext{
${ }^{6}$ See the 2020 Edition of the Demos-La Repubblica Report on the Italians and the State: http://www.demos.it/rapporto.php
} 

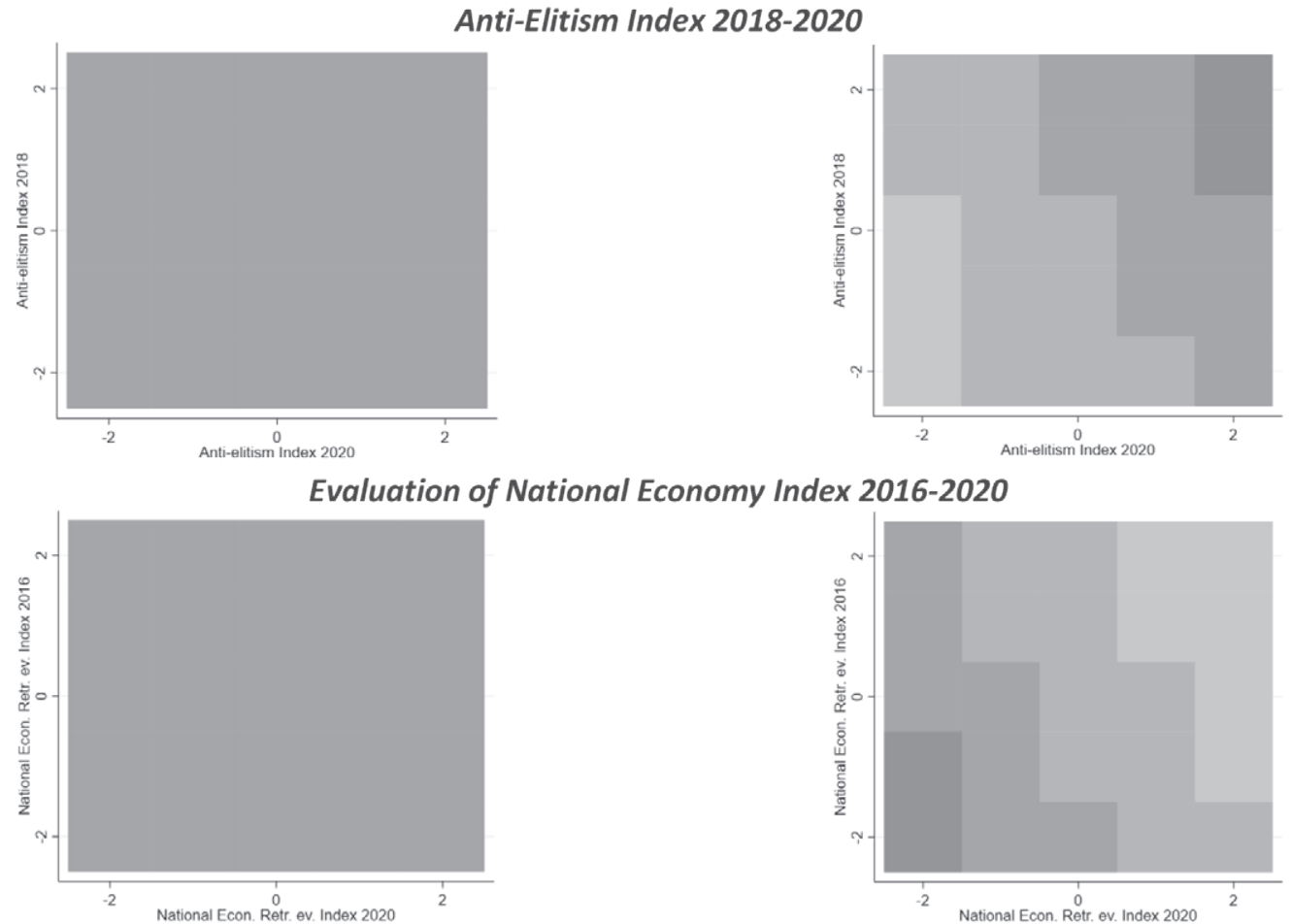

Euro-Scepticism Index 2016-2020
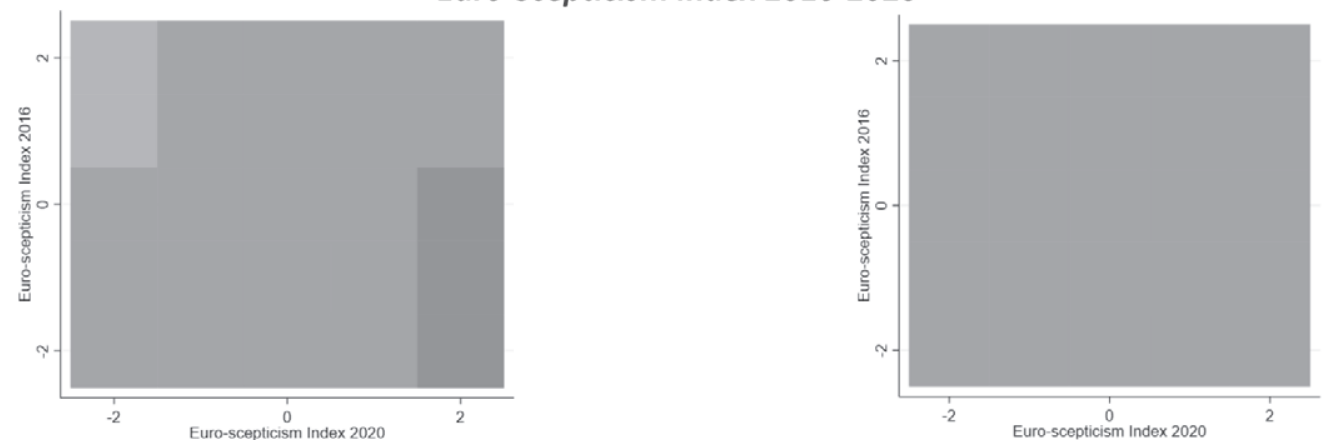

Anti-Immigration Index 2016-2020
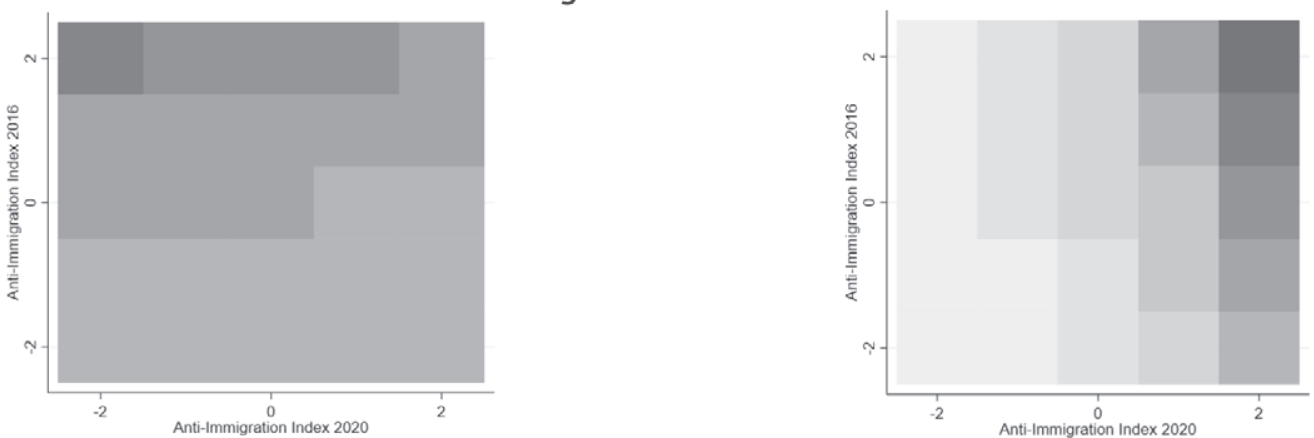

Legend

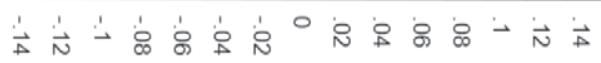

Figure 8. Differences between average probabilities of group membership (estimated through Model 3CO) and population means, at different levels of key predictors at different times - FDI. Source: ITANES panel surveys 2016-2020 (n. cases 1412). 
of popular approval towards the political elites and the attenuation of Euro-scepticism can be at least partially explained by a "rally 'round the flag» effect (Mueller 1970). However, the health emergency also fuelled economic uncertainty and temporarily (partially) overshadowed the immigration issue.

2. At the same time, the expectations associated with Hypothesis H1c have only been partially confirmed. One of the most striking changes revealed by the results concerns the redefinition of the political outlook of the M5S electorate, which significantly reduced its anti-elite attitudes. It was actually the party that experienced the deepest metamorphosis during the observation period: a protest party rapidly transformed itself into a government party. In the fall of 2020 , its voters were the least critical of Italy's economic performance. They ranked below average in terms of xenophobic attitudes. Moreover, positive opinions about the role of the EU prevailed in their view. The opposite was found just a few years earlier, in 2016. The process of a difficult (and still incomplete) institutionalisation of the movement's elites has then coincided with a redefinition of the perspectives of the electoral base. However, it has also coincided with a halving of the party's electoral attractiveness.

3. The results of the multivariate models presented in section 8 provide important insights into this process. It was the 5-Star voters who already expressed higher levels of anti-elitism and Euro-scepticism in the 20162018 phase - and maintained (or strengthened) these attitudes over the following four years - who mainly left the party. Although loyal M5S voters were not significantly characterised by anti-elitism over the analysed timeframe, their views were marked by a significant reduction of critical evaluations about the state of the economy and about the role of the EU. On the contrary, anti-elite sentiments and feelings of dissatisfaction connected to the main protest drivers were largely maintained by the voters of right-wing parties, which were the main recipients of vote outflows from the 5-Star electorate. Multinomial logit models reveal that both the loyal and incoming components of centre-right challenger parties were more characterised by a strong ideological view and consistently oriented towards issues such as xenophobia and Euro-scepticism. However, both parties - and especially FDI after 2019 - have also grown thanks to their appeal to components of the electorate sensitive to anti-elite criticism. Thus, both Hypotheses $\mathrm{H} 2 \mathrm{a}$ and $\mathrm{H} 2 \mathrm{~b}$ also find important confirmation in the analyses. At the end of 2020, the Lega and FDI presented themselves not only as the hard-line opponents of the Conte II cabinet, but also as the main collectors of the feelings of discontent spread in the country. The Lega was able to maintain its profile as an anti-establishment party even during its participation in the government majority that supported the Conte I cabinet. It was this strategy - combined with Salvini's exuberance and (social) media appeal - that allowed the party to double its votes between 2018 and 2019, while the (unexpected) return to opposition coincided with a reversal in this electoral trend. On the contrary, Meloni's party has been able to preserve its challenger profile. From 2019 onwards, it was the only party that could claim its persistent and fierce opposition to all governments since 2011. This has allowed FDI to considerably increase its electoral appeal. This was mainly at the expense of its centre-right allies. However, FDI has also been able to attract a substantial part of the fluctuating protest area not strictly linked to a specific party.

These findings offer important clues for scholars of challenger parties and their electoral appeal. At the same time, they suggest relevant insights into an unprecedented political season that Italy (among other European countries) has been facing. In early 2021, the fall of the Conte II cabinet led to the formation of a new government led by the former President of the European Central Bank Mario Draghi. His cabinet was supported by all major parties. All except FDI, consistently with the choices made by Meloni's party during the previous ten years. As in the past, Salvini's Lega maintained its two-faced profile, as a political force both 'fighting and in government'. Meanwhile, the most disruptive political actor of the previous decade, the M5S, was continuing its long and difficult process of 'normalisation' and 'institutionalisation'.

To conclude, the evolution of the political landscape and the pandemic emergency have favoured a partial redefinition of voters' orientations. The populist wave softened between 2016 and 2020, but the area of potential protest remained large, mobile, and ready to head in different directions. The (social and economic) consequences of Covid restrictions could widen this further. This might enlarge the space for old and new political actors willing (and prepared) to interpret it.

\section{ACKNOWLEDGEMENTS}

We wish to thank ITANES for having provided the data used in the article. Special thanks go to the blind referees, the guest editors of this special issue, Diego Garzia and Gianluca Passarelli, and the journal editors, Paolo Bellucci and Silvia Bolgherini, whose useful comments and help have significantly improved the article. 


\section{REFERENCES}

Albertazzi D and McDonnell D (2008) (eds) Twenty-First Century Populism. London: Palgrave Macmillan.

Angelucci D and De Sio L (2021) Issue characterization of electoral change (and how recent elections in Western Europe were won on economic issues). Quaderni dell'Osservatorio elettorale - Italian Journal of Electoral Studies, 84(1): 45-67. doi: 10.36253/qoe-10836.

Barisione M, Bellucci P and Vezzoni C (2018) Conclusioni. «Cornice» politica e risposta elettorale in ITANES (2018): 239-246.

Bellucci P (2018) Introduction: why populism won. Contemporary Italian Politics, 10(3): 218-223.

Bellucci P and Conti N (2012) (eds) Gli italiani $e$ l'Europa. Opinione pubblica, élite politiche e media. Roma: Carocci.

Bentivegna S (2015) A colpi di tweet. La politica in prima persona. Bologna: Il Mulino.

Biorcio R and Natale P (2018) Il Movimento 5 stelle: dalla protesta al governo. Milano: Mimesis.

Bordignon F (2014) Il partito del capo. Da Berlusconi a Renzi. Rimini: Maggioli.

Bordignon F and Ceccarini L (2013) Five Stars and a Cricket. Beppe Grillo Shakes Italian Politics. South European Society and Politics, 18(4): 427-449

Bordignon F, Ceccarini L and Diamanti I (2017) L'Italia del Si e l'Italia del No. Evoluzione e profilo del voto referendario in Pritoni A, Valbruzzi M and Vignati $\mathrm{R}$ (2018) (eds): 127-148.

Bordignon F, Ceccarini L and Diamanti I (2018) Le divergenze parallele. L'Italia dal voto devoto al voto liquido. Roma-Bari: Laterza.

Bosco A and McDonnell D (2012) (eds) Italian Politics 2011. From Berlusconi to Monti. New York-Oxford: Berghahn.

Caiani M and Graziano P R (2016) Varieties of populism: insights from the Italian case. Italian Political Science Review / Rivista Italiana di Scienza Politica, 46(2): 243-267.

Ceccarini L (2018) Un nuovo cleavage? I perdenti e $i$ vincenti (della globalizzazione) in Bordignon F, Ceccarini L and Diamanti I (2018): 156-182.

Ceccarini L and Bordignon F (2016) The five stars continue to shine: the consolidation of Grillo's 'movement party' in Italy. Contemporary Italian Politics, 8(2): 131-159.

Ceccarini L and Bordignon F (2017) Referendum on Renzi: The 2016 Vote on the Italian Constitutional Revision. South European Society and Politics, 22(3): 281-302.
Ceccarini L, Diamanti I and Lazar M (2012) The End of an Era. The Crumbling of the Italian Party System in Bosco A and McDonnell D (2012) (eds): 57-77.

Ceccarini L and Newell J L (2019) (eds) The Italian General Election of 2018. London: Palgrave Macmillan.

Chiaramonte A, Emanuele V, Maggini N and Paparo A (2018) Populist success in a hung parliament: the 2018 general election in Italy. South European Society and Politics, 23(4): 479-501.

Crouch C (2020) Combattere la Postdemocrazia. RomaBari: Laterza.

Conti N (2014) (ed) Party Attitudes Towards the EU in the Member States. Parties for Europe, Parties Against Europe. Abingdon-New York: Routledge.

Corbetta P and Gualmini E (2013) (eds) Il partito di Grillo. Bologna: Il Mulino.

Diamanti I, Bordignon F and Ceccarini L (2013) Un salto nel voto Ritratto politico dell'Italia di oggi. Roma-Bari: Laterza.

Diamanti I and Natale P (2014) (eds) The Five-star Movement: A new political actor on the web, in the streets and on stage. Special Issue. Contemporary Italian Politics, 6(1): 4-101.

Diamanti I and Lazar M (2018) Popolocrazia. Come cambiano le nostre democrazie. Roma-Bari: Laterza.

Emanuele V and Paparo A (2018) (eds) Gli sfidanti al governo. Disincanto, nuovi conflitti e diverse strategie dietro il voto del 4 marzo 2018. Rome: LUISS University Press.

Garzia D (2014) Personalization of Politics and Electoral Change. London: Palgrave Macmillan

Inglehart R F and Norris P (2016) Trump, Brexit, and the Rise of Populism: Economic Have-Nots and Cultural Backlash in Harvard Kennedy School, Faculty Research Working Paper Series.

ITANES (2018) Vox populi. Il voto ad alta voce del 2018. Bologna: Il Mulino.

Meny Y and Surel Y (2002) (eds) Democracy and the populist challenge. London: Palgrave Macmillan.

Kriesi H, Grande E, Lachat R, Dolezal M, Bornschier S and Frey $\mathrm{T}$ (2006). Globalization and the transformation of the national political space: Six European countries compared. European Journal of Political Research, 45(6): 921-956.

Mair P (2013) Ruling the void. The Hollowing of Western Democracy. London: Verso.

Morlino L and Raniolo F (2017) The Impact of the Economic Crisis on South European Democracy. London: Palgrave Macmillan.

Mounk Y (2018) The People Vs. Democracy. Why Our Freedom is in Danger \& How to Save it. Cambridge (MA): Harvard University Press. 
Mudde C (2004) The populist zeitgeist. Government and Opposition, 39(4): 541-563.

Muller J E (1973) War, Presidents, and Public Opinion. New York: Wiley.

Novelli E (2016) La democrazia del talk show. Storia di un genere che ha cambiato la televisione, la politica, l'Italia. Roma: Carocci.

Pasquino G (2019) The Formation of the Government in Ceccarini L and Newell J L (2019) (eds): 297-315.

Passarelli G and Tuorto D (2018) La Lega di Salvini. Estrema destra di governo. Bologna: Il Mulino.

Pritoni A, Valbruzzi M and Vignati R (2018) (eds) La prova del No. Il sistema politico italiano dopo il referendum costituzionale. Soveria Mannelli: Rubettino.

Qvortrup M (2018). Government by referendum. Manchester: Manchester University Press.

Rovira Kaltwasser C and Taggart P (2016) Dealing with Populists in Government: A Framework for Analysis. Democratization, 23(2): 201-220.

Tarchi M (2015) Italia populista. Dal qualunquismo a Beppe Grillo. Bologna: Il Mulino.

Tronconi F (2018) The Italian Five Star Movement during the Crisis: Towards Normalisation? South European Society and Politics, 23(1): 163-180.

Uleri P V (2003) Referendum e democrazia. Una prospettiva comparata. Bologna: Il Mulino.

Valbruzzi M (2019) Issues and Themes in Ceccarini L and Newell J L (2019) (eds): 167-190.

Ventura S (2015) Renzi \& Co. Il racconto dellera nuova. Soveria Mannellli: Rubettino.

Vezzoni C (2018) Immigrazione e insicurezza economica nelle urne in ITANES (2018): 147-163. 


\section{APPENDIX}

Table A.1. Populism indicators (\% of respondents who strongly or somewhat agree with each statement in 2020; 2018 pre-electoral data in parentheses).

\begin{tabular}{|c|c|c|c|c|c|c|}
\hline & $\mathrm{PD}$ & M5S & FI & Lega & FDI & Pop. \\
\hline \multicolumn{7}{|l|}{ People-centrism indicators: } \\
\hline MPs must follow the will of the citizens & $\begin{array}{c}71 \\
(82)\end{array}$ & $\begin{array}{c}85 \\
(90)\end{array}$ & $\begin{array}{c}84 \\
(87)\end{array}$ & $\begin{array}{c}86 \\
(91)\end{array}$ & $\begin{array}{c}84 \\
(86)\end{array}$ & $\begin{array}{c}75 \\
(83)\end{array}$ \\
\hline Citizens, not politicians, should make the most important political decisions & $\begin{array}{c}27 \\
(36)\end{array}$ & $\begin{array}{c}45 \\
(70)\end{array}$ & $\begin{array}{c}38 \\
(58)\end{array}$ & $\begin{array}{c}50 \\
(69)\end{array}$ & $\begin{array}{c}48 \\
(61)\end{array}$ & $\begin{array}{c}38 \\
(54)\end{array}$ \\
\hline I would rather be represented by an ordinary person than a professional politician & $\begin{array}{c}21 \\
(27)\end{array}$ & $\begin{array}{c}47 \\
(77)\end{array}$ & $\begin{array}{c}31 \\
(50)\end{array}$ & $\begin{array}{c}43 \\
(60)\end{array}$ & $\begin{array}{c}46 \\
(43)\end{array}$ & $\begin{array}{c}34 \\
(51)\end{array}$ \\
\hline \multicolumn{7}{|l|}{ Anti-elitism indicators: } \\
\hline $\begin{array}{l}\text { The differences between the politicians and the people are greater than the differences } \\
\text { within the people }\end{array}$ & $\begin{array}{c}53 \\
(52)\end{array}$ & $\begin{array}{c}57 \\
(77)\end{array}$ & $\begin{array}{c}61 \\
(68)\end{array}$ & $\begin{array}{c}69 \\
(73)\end{array}$ & $\begin{array}{c}67 \\
(66)\end{array}$ & $\begin{array}{c}58 \\
(64)\end{array}$ \\
\hline Politicians talk a lot but do little & $\begin{array}{c}76 \\
(73)\end{array}$ & $\begin{array}{c}75 \\
(91)\end{array}$ & $\begin{array}{c}82 \\
(84)\end{array}$ & $\begin{array}{c}88 \\
(91)\end{array}$ & $\begin{array}{c}92 \\
(88)\end{array}$ & $\begin{array}{c}81 \\
(83)\end{array}$ \\
\hline Making compromises in politics actually means selling out one's principles & $\begin{array}{c}29 \\
(39)\end{array}$ & $\begin{array}{c}45 \\
(71)\end{array}$ & $\begin{array}{c}58 \\
(62)\end{array}$ & $\begin{array}{c}58 \\
(71)\end{array}$ & $\begin{array}{c}64 \\
(71)\end{array}$ & $\begin{array}{c}45 \\
(56)\end{array}$ \\
\hline
\end{tabular}

Source:

- ITANES panel surveys 2016-2020 (n. cases 1412)

- ITANES pre-electoral rolling cross-section survey 2018 (n. cases 5528)

Table A.2. Multinomial Logistic Models (Dep. Var. M5s Typology 2016-2020; Reference category: Other).

\begin{tabular}{|c|c|c|c|c|c|c|c|c|c|c|c|c|c|c|c|c|c|c|}
\hline & & & Mo & del 1L & & & & & Moc & del $2 \mathrm{~L}$ & & & & & Mo & del 3L & & \\
\hline & & oyal & Ou & tgoing & Ince & oming & & oyal & Out & tgoing & Ince & oming & & oyal & Out & tgoing & Inco & oming \\
\hline Intercept & $\begin{array}{c}\text { B } \\
-1.480\end{array}$ & $\begin{array}{l}\text { s.e. Sig. } \\
.520 \text { * }\end{array}$ & $\begin{array}{c}\mathrm{B} \\
-1.328\end{array}$ & $\begin{array}{l}\text { s.e. Sig. } \\
.392\end{array}$ & $\begin{array}{c}\text { B } \\
-3.257\end{array}$ & $\begin{array}{l}\text { s.e. Sig. } \\
.678^{\star \star \star}\end{array}$ & $\begin{array}{c}\text { B } \\
-1.570\end{array}$ & $\begin{array}{l}\text { s.e. Sig. } \\
.549 * \star\end{array}$ & $\begin{array}{c}B \\
-1.618\end{array}$ & $\begin{array}{l}\text { s.e. Sig } \\
.411^{* \star *}\end{array}$ & $\begin{array}{c}B \\
-3.370\end{array}$ & $\begin{array}{l}\text { s.e. Sig. } \\
.711^{\star \star \star}\end{array}$ & $\begin{array}{c}\text { B } \\
-1.149\end{array}$ & $\begin{array}{l}\text { s.e. Sig. } \\
.570 *\end{array}$ & $\begin{array}{c}\text { B } \\
-1.432\end{array}$ & $\begin{array}{l}\text { s.e. Sig. } \\
.425 * \star \star\end{array}$ & $\begin{array}{c}B \\
-2.991\end{array}$ & $\begin{array}{l}\text { s.e. Sig. } \\
.719^{\star \star \star}\end{array}$ \\
\hline Gender: female & -.767 & $.226^{\star \star \star}$ & -.347 & $.154 *$ & .456 & .260 & -.808 & $.228^{\star \star *}$ & -.359 & .156 * & .483 & .264 & -.975 & $.236^{\star \star \star}$ & -.460 & .160 ** & .446 & .270 \\
\hline Age & -.015 & .007 * & -.011 & .005 * & -.005 & .009 & -.016 & $.007^{*}$ & -.009 & .006 & -.007 & .009 & -.016 & .008 & -.012 & .006 * & -.006 & .009 \\
\hline Education: secondary & -.486 & .261 & .207 & .205 & .144 & .341 & -.399 & .270 & .372 & .211 & .072 & .348 & -.408 & .276 & .334 & .213 & .089 & .352 \\
\hline Education: tertiary & -.345 & .358 & -.073 & .294 & .339 & .447 & -.241 & .374 & .210 & .303 & .214 & .460 & -.235 & .383 & .109 & .310 & .261 & .465 \\
\hline Region: Centre (ex-red zone) & -810 & .539 & -.033 & .240 & .402 & .391 & -.831 & .540 & -.020 & .244 & .366 & .392 & -.984 & .544 & -.130 & .249 & .291 & .397 \\
\hline Region: South and Islands & 1.068 & $.239^{\star \star \star}$ & .253 & .164 & .662 & .284 * & 1.024 & $.243^{* \star *}$ & .179 & .168 & .726 & .289 * & .963 & $.246^{\star \star *}$ & .122 & .170 & .685 & .292 * \\
\hline National Econ. Retr. ev. Index 2016 & & & & & & & -.488 & $.140^{* \star \star}$ & -.267 & $.103^{* \star}$ & .034 & .173 & -.490 & $.140^{* \star *}$ & -.263 & $.105^{*}$ & .019 & .173 \\
\hline Household Econ. Retr. ev. Index 2016 & & & & & & & .142 & .157 & -.071 & .112 & -.148 & .194 & .127 & .162 & -.084 & .115 & -.111 & .198 \\
\hline Anti-Immigration Index 2016 & & & & & & & -.139 & .095 & -.148 & .070 * & .073 & .115 & -.083 & .097 & -.068 & .073 & .067 & .121 \\
\hline Euroscepticism Index 2016 & & & & & & & .007 & .083 & .232 & $.059 * \star *$ & -.249 & $.101 *$ & .074 & .087 & .320 & $.062 * \star *$ & -.240 & .106 * \\
\hline Anti-elitism Index 2018 & .159 & .121 & .413 & $.092 * \star$ & .048 & .146 & .088 & .126 & .334 & $.095^{* * *}$ & .067 & .151 & .143 & .130 & .351 & $.097^{\star \star \star \star}$ & .092 & .153 \\
\hline L-R self-placement: Left & & & & & & & & & & & & & -.144 & .334 & .678 & .243 ** & -1.049 & .484 * \\
\hline L-R self-placement: Centre-Left & & & & & & & & & & & & & -.458 & .383 & .396 & .269 & -.384 & .404 \\
\hline L-R self-placement: Centre & & & & & & & & & & & & & -.002 & .379 & .264 & .294 & .201 & .393 \\
\hline L-R self-placement: Centre-Right & & & & & & & & & & & & & -.403 & .320 & -.230 & .261 & -.562 & .417 \\
\hline L-R self-placement: Right & & & & & & & & & & & & & -2.396 & $.580^{\star \star \star}$ & -.845 & .262 ** & -1.263 & .531 * \\
\hline Ps eudo $R^{2}$ & $\begin{array}{l}\text { Cox \& } \\
\text { Nagelke } \\
\text { McFadd }\end{array}$ & $\begin{array}{l}\text { Snell } .064 \\
\text { rerke .079 } \\
\text { Iden .040 }\end{array}$ & & & & & $\begin{array}{l}\text { Cox \& } \\
\text { Nagelk } \\
\text { McFad }\end{array}$ & $\begin{array}{l}\text { Snell .100 } \\
\text { terke .123 } \\
\text { Iden .063 }\end{array}$ & & & & & $\begin{array}{l}\text { Cox \& } \\
\text { Nagelk } \\
\text { McFad }\end{array}$ & $\begin{array}{l}\text { Snell .142 } \\
\text { rerke .175 } \\
\text { Iden .091 }\end{array}$ & & & & \\
\hline
\end{tabular}

Note: Sig. indicates the level of significance; ${ }^{\star} \mathrm{p}<0.05{ }^{* *} \mathrm{p}<0.01 ;{ }^{* *} \mathrm{p}<0.001$.

Source: ITANES panel surveys 2016-2020 (n. cases 1412). 
Table A.3. Multinomial Logistic Models (Dep. Var. M5s Typology 2016-2020; Reference category: Other).

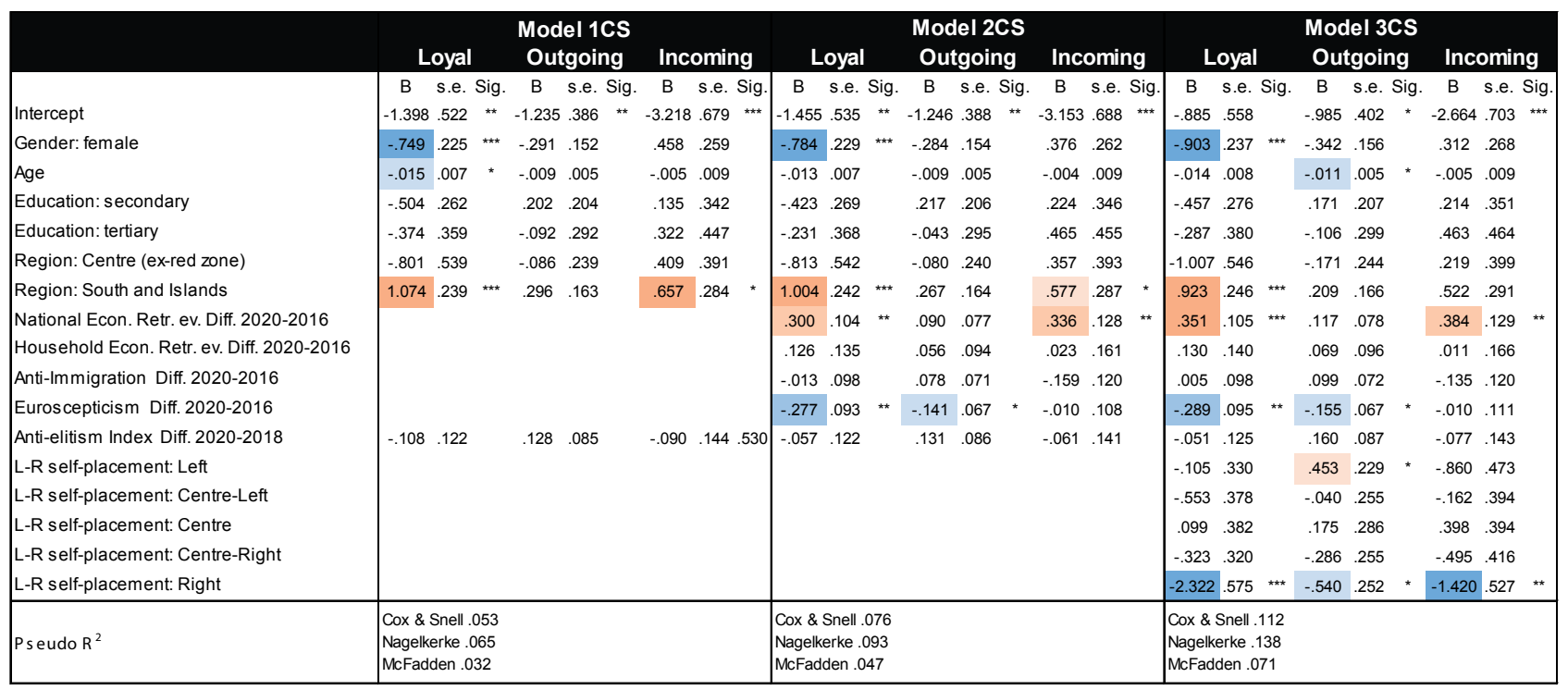

Note: Sig. indicates the level of significance; ${ }^{*} \mathrm{p}<0.05 ;{ }^{* *} \mathrm{p}<0.01 ;{ }^{* *} \mathrm{p}<0.001$.

Source: ITANES panel surveys 2016-2020 (n. cases 1412).

Table A.4. Multinomial Logistic Models (Dep. Var. M5s Typology 2016-2020; Reference category: Other).

\begin{tabular}{|c|c|c|c|c|c|c|c|c|c|c|c|c|c|c|c|c|c|c|c|c|c|c|c|c|c|}
\hline & \multicolumn{7}{|c|}{ Model $1 \mathrm{CO}$} & \multicolumn{9}{|c|}{ Model 2CO } & \multicolumn{9}{|c|}{ Model $3 \mathrm{CO}$} \\
\hline & \multicolumn{2}{|c|}{ Loyal } & \multicolumn{3}{|c|}{ Outgoing } & \multicolumn{2}{|c|}{ Incoming } & \multicolumn{3}{|c|}{ Loyal } & \multicolumn{3}{|c|}{ Outgoing } & \multicolumn{3}{|c|}{ Incoming } & \multicolumn{3}{|c|}{ Loyal } & \multicolumn{3}{|c|}{ Outgoing } & \multicolumn{3}{|c|}{ Incoming } \\
\hline & $B$ & s.e. Sig. & B & s.e. & Sig. & B & s.e. Sig. & B & s.e. & Sig. & B & s.e. & Sig. & B & s.e. $s$ & Sig. & B & s.e. & Sig. & B & s.e. & Sig. & B & s.e. $s$ & Sig. \\
\hline Intercept & -1.455 & 5.525 ** & -1.665 & .404 & $\star \star *$ & -3.219 & $.680^{* * *}$ & -1.414 & 4.572 & * & -1.942 & .433 & $* \star \star$ & -2.985 & 5.724 & $* * *$ & -.997 & .594 & & -1.751 & .447 & $* * *$ & -2.529 & .736 & $\star \star * *$ \\
\hline Gender: female & -.771 & .226 *** & -.357 & .155 & * & .464 & .261 & -.816 & .233 & $* * *$ & -.369 & .158 & * & .477 & .269 & & -.972 & .242 & $* * *$ & -.470 & .162 & $* *$ & .478 & .278 & \\
\hline Age & -.015 & $.007 *$ & -.013 & .005 & * & -.005 & .009 & -.018 & .008 & * & -.013 & .006 & * & -.005 & .009 & & -.017 & .008 & * & -.016 & .006 & ** & -.003 & .010 & \\
\hline Education: secondary & -.500 & .262 & .269 & .208 & & .140 & .342 & -.487 & .278 & & .323 & .214 & & .064 & .356 & & -.476 & .284 & & .294 & .216 & & .090 & .360 & \\
\hline Education: tertiary & -.359 & .360 & .033 & .297 & & .326 & .448 & -.385 & .383 & & .126 & .309 & & .240 & .468 & & -.346 & .392 & & .054 & .314 & & .292 & .473 & \\
\hline Region: Centre (ex-red zone) & -.807 & .539 & -.133 & .244 & & .408 & .391 & -.840 & .545 & & -.104 & .250 & & .324 & .397 & & -1.005 & .549 & & -.192 & .254 & & .226 & .402 & \\
\hline Region: South and Islands & 1.069 & $.239^{* * *}$ & .267 & .165 & & .659 & $.285 *$ & 1.027 & .246 & $* * \star$ & .189 & .170 & & .583 & .295 & * & .961 & .250 & $* * *$ & .134 & .173 & & .526 & .298 & \\
\hline National Econ. Retr. ev. Index 2016 & & & & & & & & -.475 & .181 & ** & -.460 & .144 & ** & .571 & .226 & * & -.423 & .184 & * & -.422 & .148 & ** & .623 & .230 & ** \\
\hline Household Econ. Retr. ev. Index 2016 & & & & & & & & .402 & .202 & * & -.037 & .140 & & -.215 & .238 & & .370 & .204 & & -.059 & .144 & & -.178 & .242 & \\
\hline Anti-Immigration Index 2016 & & & & & & & & -.119 & .117 & & -.261 & .086 & ** & .076 & .134 & & -.065 & .120 & & -.145 & .090 & & .079 & .141 & \\
\hline Euroscepticism Index 2016 & & & & & & & & -.114 & .097 & & .176 & .068 & * & -.313 & .118 & ** & -.046 & .102 & & .257 & .071 & $* \star *$ & -.330 & .128 & ** \\
\hline Anti-elitism Index 2018 & .150 & .150 & .800 & .120 & $* \star *$ & -.022 & .186 & .136 & .174 & & .734 & .134 & *** & .117 & .205 & & .185 & .179 & & .749 & .136 & $* \star *$ & .103 & .207 & \\
\hline National Econ. Retr. ev. Diff. 2020-2016 & & & & & & & & .089 & .140 & & -.273 & .115 & * & .659 & .164 & $* \star \star$ & .135 & .143 & & -.237 & .118 & * & .741 & .169 & *** \\
\hline Household Econ. Retr. ev. Diff. 2020-2016 & & & & & & & & .337 & .173 & & .004 & .115 & & -.080 & 207 & & .323 & .176 & & 0.016 & .117 & & -0.111 & .215 & \\
\hline Anti-Immigration Diff. 2020-2016 & & & & & & & & -.090 & .112 & & -.093 & .086 & & -.130 & .134 & & -.056 & .114 & & -.022 & .091 & & -.114 & .134 & \\
\hline Euroscepticism Diff. 2020-2016 & & & & & & & & -.333 & .108 & ** & -.042 & .076 & & -.196 & .131 & & -.303 & .111 & ** & -.017 & .078 & & -.222 & .137 & \\
\hline Anti-elitism Index Diff. 2020-2018 & -.018 & .151 & .620 & .117 & $\star \star \star *$ & -.104 & .181 & .057 & .169 & & .559 & .131 & *** & .103 & .203 & & .071 & .172 & & .568 & .133 & $* * *$ & .062 & .204 & \\
\hline L-R self-placement: Left & & & & & & & & & & & & & & & & & -.125 & .343 & & .671 & .248 & $* *$ & -1.258 & .497 & * \\
\hline L-R self-placement: Centre-Left & & & & & & & & & & & & & & & & & -.549 & .387 & & .409 & .273 & & -.555 & .418 & \\
\hline L-R self-placement: Centre & & & & & & & & & & & & & & & & & .070 & .387 & & .135 & .297 & & .212 & .407 & \\
\hline L-R self-placement: Centre-Right & & & & & & & & & & & & & & & & & -.356 & .326 & & -.241 & .264 & & -.608 & .431 & \\
\hline L-R self-placement: Right & & & & & & & & & & & & & & & & & -2.295 & 5.582 & $* * *$ & -.878 & .267 & ** & -1.353 & .539 & * \\
\hline Ps eudo $R^{2}$ & $\begin{array}{l}\text { Cox \& } \\
\text { Nagelk } \\
\text { McFad }\end{array}$ & $\begin{array}{l}\text { Snell } .084 \\
\text { kerke .104 } \\
\text { dden } .052\end{array}$ & & & & & & $\begin{array}{l}\text { Cox \& } \\
\text { Nagelk } \\
\text { McFad }\end{array}$ & $\begin{array}{l}\text { Snell . } \\
\text { kerke .1 } \\
\text { dden .0 }\end{array}$ & & & & & & & & $\begin{array}{l}\text { Cox \& } \\
\text { Nagelk } \\
\text { McFad }\end{array}$ & $\begin{array}{l}\text { Snell . } \\
\text { kerke .2 } \\
\text { Aden .1 }\end{array}$ & & & & & & & \\
\hline
\end{tabular}

Note: Sig. indicates the level of significance; ${ }^{\star} \mathrm{p}<0.05$; $^{* *} \mathrm{p}<0.01$; ${ }^{* *} \mathrm{p}<0.001$.

Source: ITANES panel surveys 2016-2020 (n. cases 1412). 
Table A.5. Multinomial Logistic Models (Dep. Var. Lega Typology 2016-2020; Reference category: Other).

\begin{tabular}{|c|c|c|c|c|c|c|c|c|c|c|c|c|c|c|c|c|c|c|c|c|c|c|c|c|c|c|c|}
\hline & \multicolumn{9}{|c|}{ Model 1L } & \multicolumn{9}{|c|}{ Model 2L } & \multicolumn{9}{|c|}{ Model 3L } \\
\hline & \multicolumn{3}{|c|}{ Loyal } & \multicolumn{3}{|c|}{ Outgoing } & \multicolumn{3}{|c|}{ Incoming } & \multicolumn{3}{|c|}{ Loyal } & \multicolumn{3}{|c|}{ Outgoing } & \multicolumn{3}{|c|}{ Incoming } & \multicolumn{3}{|c|}{ Loyal } & \multicolumn{3}{|c|}{ Outgoing } & \multicolumn{3}{|c|}{ Incoming } \\
\hline & B & s.e. & Sig. & B & s.e. & Sig. & B & s.e. & Sig. & B & s.e. & Sig. & B & s.e. & Sig. & B & s.e. & Sig. & B & s.e. & Sig. & B & s.e. & Sig. & B & s.e. & Sig. \\
\hline Intercept & -1.834 & .538 & 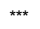 & -2.252 & .672 & $\star * \star *$ & -2.090 & .451 & $* \star \star$ & -4.240 & .696 & 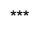 & -4.133 & .806 & $\star \star \star *$ & -2.568 & .476 & $* \star \star \star$ & $\mid-5.085$ & .753 & $* \star *$ & -5.626 & .946 & $* \star *$ & -2.663 & .486 & $\star \star \star \star *$ \\
\hline Gender: female & -.103 & .216 & & .337 & .274 & & .187 & .177 & & -.066 & .232 & & .320 & .285 & & .159 & .180 & & 0.246 & .249 & & 0.647 & .299 & * & 0.232 . & .183 & \\
\hline Age & .000 & .008 & & -.001 & .009 & & .006 & .006 & & .007 & .008 & & .004 & .010 & & .009 & .006 & & 0.009 & .009 & & 0.003 & .011 & & 0.011 . & .007 & \\
\hline Education: secondary & -.167 & .260 & & -.205 & .320 & & -.212 & .210 & & .196 & .281 & & .077 & .335 & & -.054 & .215 & & 0.132 & .303 & & -0.087 & .355 & & -0.036 & .218 & \\
\hline Education: tertiary & -.779 & .449 & & -1.191 & .634 & & -.878 & .368 & * & -.179 & .482 & & -.681 & .658 & & -.644 & .375 & & -0.395 & .510 & & -1.095 & .684 & & -0.663 & .379 & \\
\hline Region: Centre (ex-red zone) & -.616 & .331 & & -.369 & .384 & & .134 & .251 & & -.594 & .352 & & -.333 & .400 & & .163 & .255 & & -0.296 & .374 & & 0.031 & .421 & & 0.213 & .258 & \\
\hline Region: South and Islands & -1.418 & .266 & $* * *$ & -1.357 & .342 & $* \star *$ & -.423 & .194 & * & -1.522 & .281 & $* * *$ & -1.495 & .354 & $* \star *$ & -.460 & .199 & * & -1.490 & .297 & $* * *$ & -1.490 & .367 & $* * *$ & -0.452 & .201 & * \\
\hline National Econ. Retr. ev. Index 2016 & & & & & & & & & & .156 & .157 & & .105 & .187 & & -.053 & .119 & & 0.157 & .171 & & 0.139 & .202 & & -0.054 & .119 & \\
\hline Household Econ. Retr. ev. Index 2016 & & & & & & & & & & -.124 & .168 & & .015 & .208 & & .158 & .137 & & -0.203 & 3.182 & & -0.094 & .222 & & 0.161. & .140 & \\
\hline Anti-Immigration Index 2016 & & & & & & & & & & 1.214 & .210 & $* * *$ & 1.035 & .221 & $* * *$ & .298 & .088 & $* * \star$ & 0.964 & .205 & $* * *$ & 0.825 & .217 & $* * *$ & 0.247 & .089 & ** \\
\hline Euroscepticism Index 2016 & & & & & & & & & & .592 & .097 & $* * \star$ & .558 & .117 & $* \star *$ & 240 & .067 & $* \star \star$ & 0.482 & .106 & $\star * *$ & 0.493 & .124 & *** & 0.200 & .069 & ** \\
\hline Anti-elitism Index 2018 & .267 & .130 & * & -.115 & .156 & & .071 & .102 & & -.041 & .138 & & -.357 & .161 & * & -.035 & .106 & & -0.064 & 4.147 & & -0.334 & .170 & * & -0.033 & .107 & \\
\hline L-R self-placement: Centre/Centre-Left/Left & & & & & & & & & & & & & & & & & & & -0.567 & 7.529 & & 0.703 & .678 & & -0.496 & .245 & * \\
\hline L-R self-placement: Centre-Right & & & & & & & & & & & & & & & & & & & 1.360 & .413 & *** & 2.630 & .597 & $* \star *$ & 0.458 & .258 & \\
\hline L-R self-placement: Right & & & & & & & & & & & & & & & & & & & 2.288 & .362 & *** & 2.942 & .576 & *** & 0.282 & .273 & \\
\hline Ps eudo $R^{2}$ & $\begin{array}{l}\text { Cox \& S } \\
\text { Nagelke } \\
\text { McFadd }\end{array}$ & $\begin{array}{l}\text { Snell } \\
\text { terke .0 } \\
\text { iden .0 }\end{array}$ & & & & & & & & $\begin{array}{l}\text { Cox \& S } \\
\text { Nagelke } \\
\text { McFadd }\end{array}$ & $\begin{array}{l}\text { Snell .1 } \\
\text { erke .2 } \\
\text { den .14 }\end{array}$ & & & & & & & & $\begin{array}{l}\text { Cox \& S } \\
\text { Nagelke } \\
\text { McFado }\end{array}$ & $\begin{array}{l}\text { Snell .2 } \\
\text { kerke .3 } \\
\text { dden .2 }\end{array}$ & & & & & & & \\
\hline
\end{tabular}

Note: Sig. indicates the level of significance; ${ }^{\star} \mathrm{p}<0.05 ;{ }^{* \star} \mathrm{p}<0.01 ;{ }^{\star * \star} \mathrm{p}<0.001$.

Source: ITANES panel surveys 2016-2020 (n. cases 1412).

Table A.6. Multinomial Logistic Models (Dep. Var. Lega Typology 2016-2020; Reference category: Other).

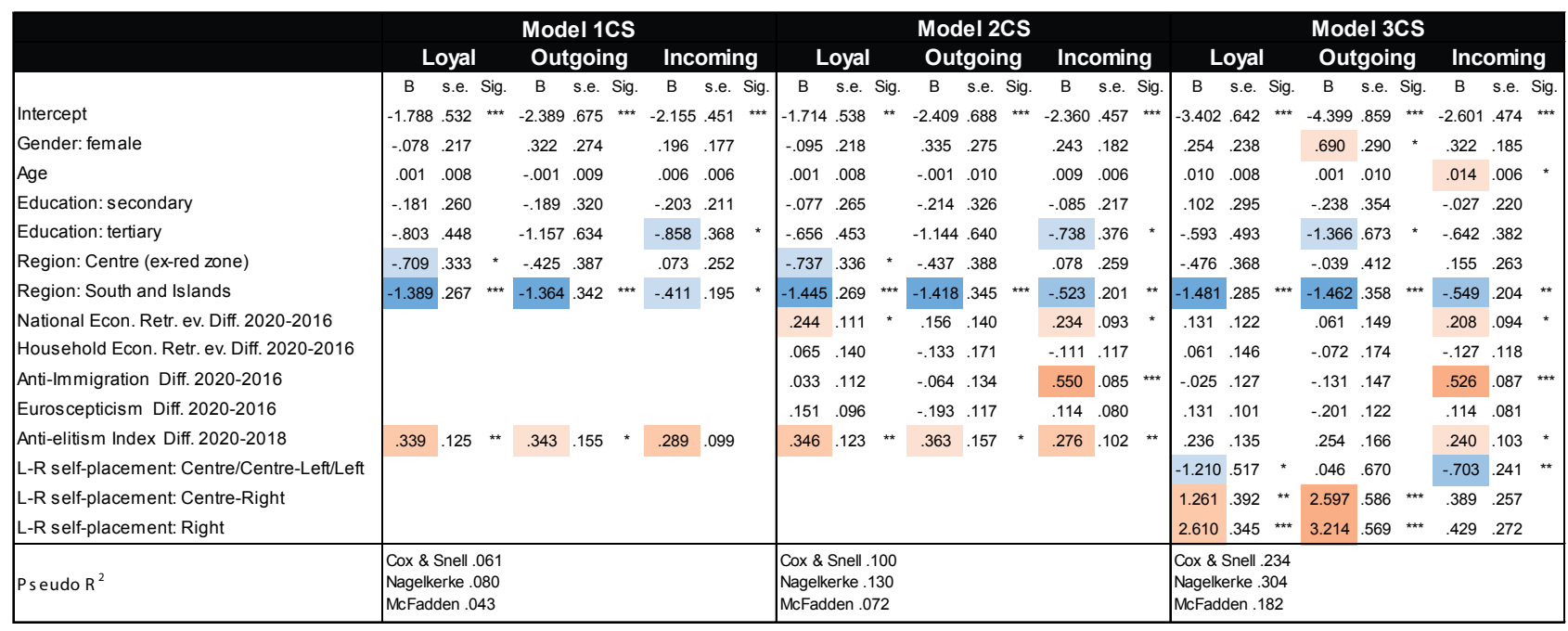

Note: Sig. indicates the level of significance; ${ }^{\star} \mathrm{p}<0.05 ;^{* *} \mathrm{p}<0.01 ;{ }^{* *} \mathrm{p}<0.001$

Source: ITANES panel surveys 2016-2020 (n. cases 1412). 
Table A.7. Multinomial Logistic Models (Dep. Var. Lega Typology 2016-2020; Reference category: Other).

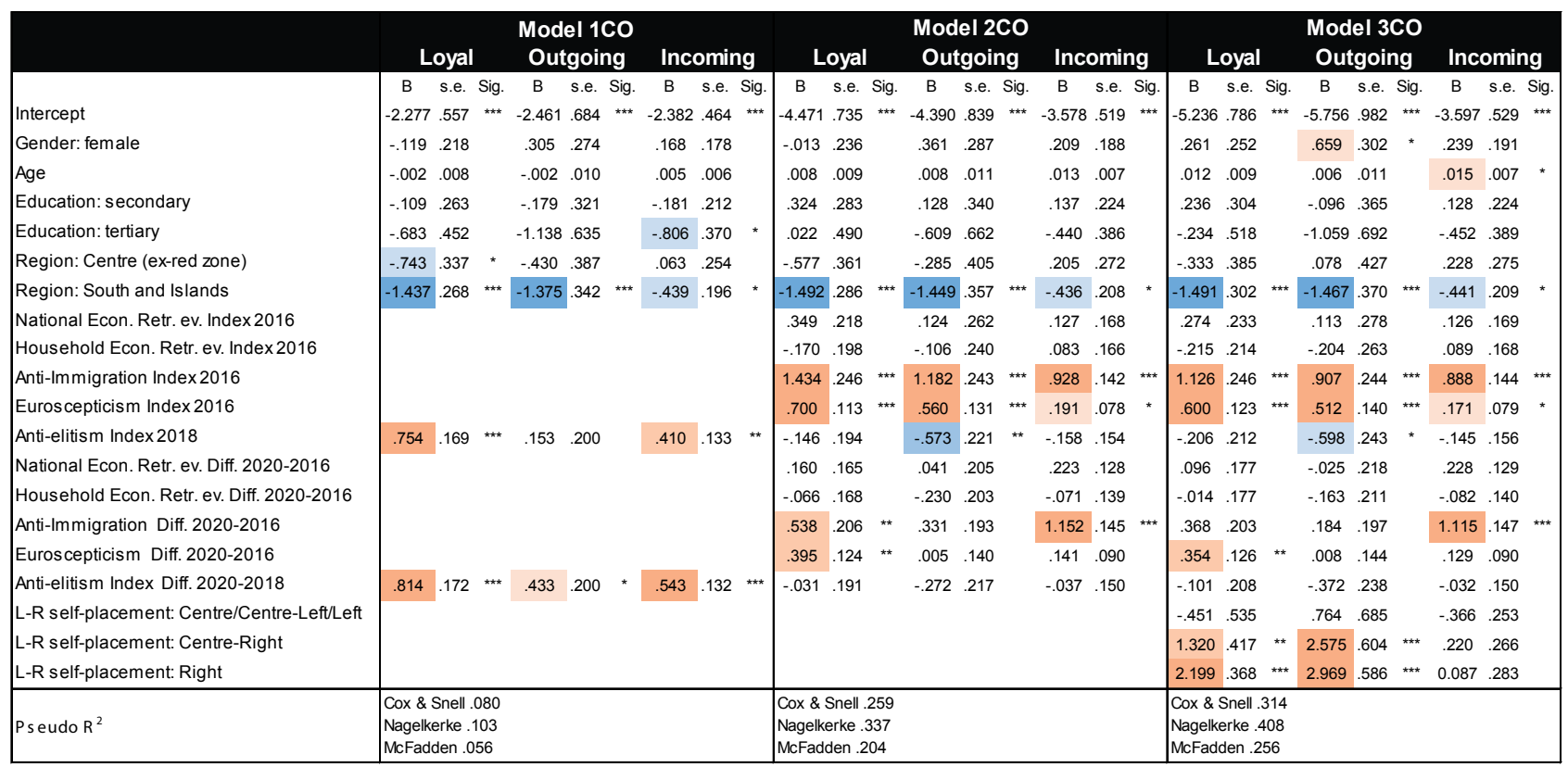

Note: Sig. indicates the level of significance; ${ }^{\star} \mathrm{p}<0.05 ;{ }^{* *} \mathrm{p}<0.01 ;{ }^{* *} \mathrm{p}<0.001$.

Source: ITANES panel surveys 2016-2020 (n. cases 1412).

Table A.8. Multinomial Logistic Models (Dep. Var. FDI Typology 2016-2020; Reference category: Other).

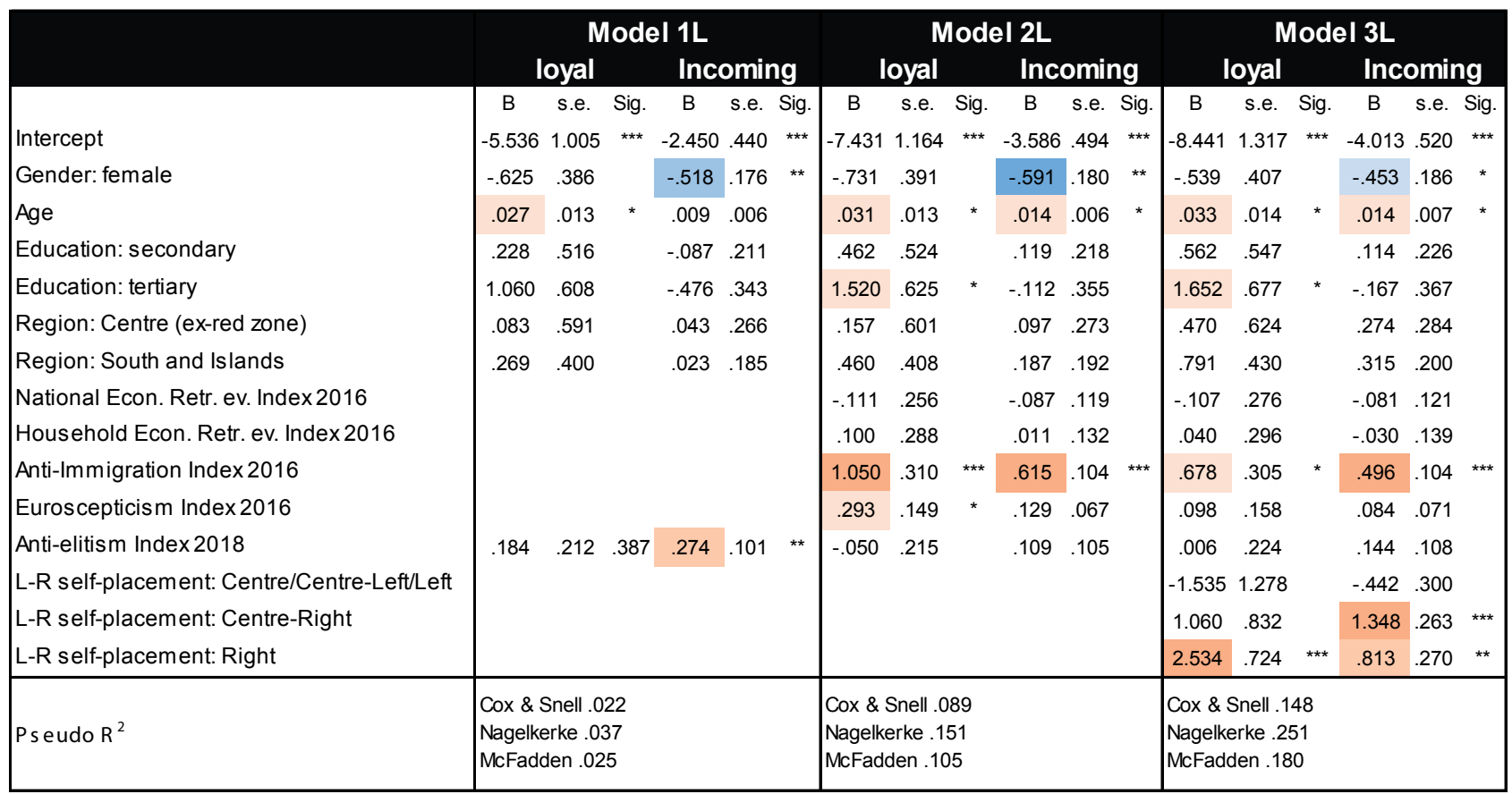

Note: Sig. indicates the level of significance; ${ }^{\star} \mathrm{p}<0.05 ;{ }^{* \star} \mathrm{p}<0.01 ;{ }^{\star * *} \mathrm{p}<0.001$.

Source: ITANES panel surveys 2016-2020 (n. cases 1412). 
Table A.9. Multinomial Logistic Models (Dep. Var. FDI Typology 2016-2020; Reference category: Other).

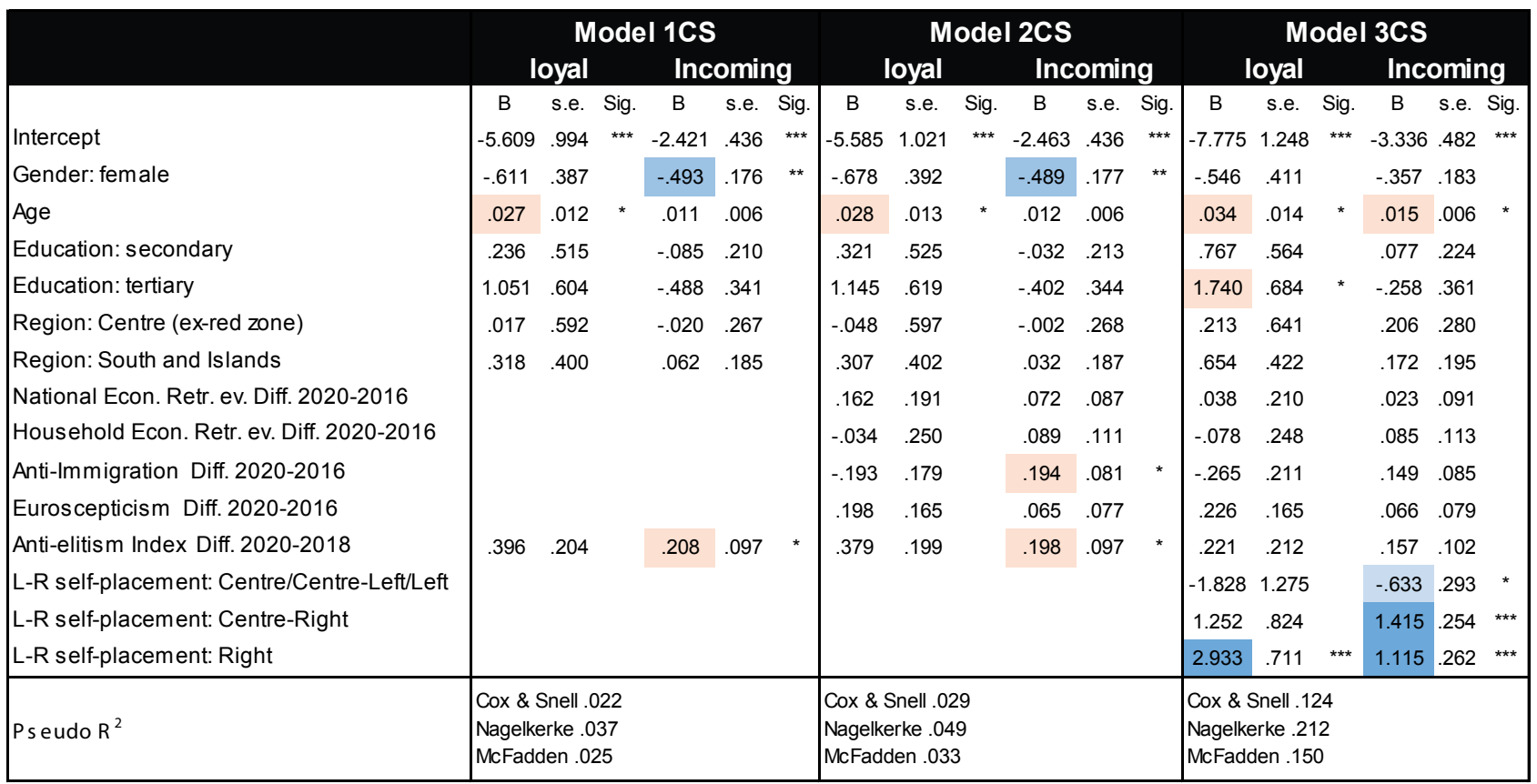

Note: Sig. indicates the level of significance; ${ }^{*} \mathrm{p}<0.05 ;{ }^{* *} \mathrm{p}<0.01 ;{ }^{* *} \mathrm{p}<0.001$.

Source: ITANES panel surveys 2016-2020 (n. cases 1412).

Table A.10. Multinomial Logistic Models (Dep. Var. FDI Typology 2016-2020; Reference category: Other).

\begin{tabular}{|c|c|c|c|c|c|c|c|c|c|c|c|c|c|c|c|c|c|c|}
\hline & \multicolumn{6}{|c|}{ Model $1 \mathrm{CO}$} & \multicolumn{6}{|c|}{ Model 2CO } & \multicolumn{6}{|c|}{ Model 3CO } \\
\hline & \multicolumn{3}{|c|}{ loyal } & \multicolumn{3}{|c|}{ Incoming } & \multicolumn{3}{|c|}{ loyal } & \multicolumn{3}{|c|}{ Incoming } & \multicolumn{3}{|c|}{ loyal } & \multicolumn{3}{|c|}{ Incoming } \\
\hline & B & s.e. & Sig. & B & s.e. & Sig. & B & s.e. & Sig. & B & s.e. & Sig. & B & s.e. & Sig. & B & s.e. & Sig. \\
\hline Intercept & -6.130 & 1.041 & $* \star \star$ & -2.828 & .455 & $* \star \star$ & -7.613 & 1.212 & $* \star *$ & -4.277 & .522 & $* \star *$ & -8.678 & 1.370 & $* * *$ & -4.691 & .553 & $* \star *$ \\
\hline Gender: female & -.658 & .387 & & -.536 & .177 & ** & -.743 & .395 & & -.555 & .183 & ** & -.592 & .413 & & -.423 & .188 & * \\
\hline Age & .026 & .013 & * & .009 & .006 & & .032 & .014 & * & .012 & .006 & & .035 & .014 & * & .013 & .007 & \\
\hline Education: secondary & .286 & .515 & & -.037 & .212 & & .551 & .526 & & .148 & .221 & & .731 & .560 & & .109 & .228 & \\
\hline Education: tertiary & 1.194 & .609 & * & -.369 & .345 & & 1.699 & .638 & ** & -.048 & .360 & & 1.894 & .700 & ** & -.137 & .374 & \\
\hline Region: Centre (ex-red zone) & -.028 & .596 & & -.045 & .270 & & .130 & .609 & & .175 & .281 & & .335 & .641 & & .292 & .291 & \\
\hline Region: South and Islands & .299 & .401 & & .037 & .187 & & .484 & .412 & & .270 & .197 & & .766 & .433 & & .369 & .204 & \\
\hline National Econ. Retr. ev. Index 2016 & & & & & & & -.089 & .363 & & -.189 & .167 & & -.168 & .380 & & -.214 & .168 & \\
\hline Household Econ. Retr. ev. Index 2016 & & & & & & & .073 & .341 & & .098 & .159 & & .046 & .361 & & .059 & .165 & \\
\hline Anti-Immigration Index 2016 & & & & & & & .968 & .337 & $\star \star$ & 1.019 & .144 & *** & .510 & .339 & & .865 & .147 & *** \\
\hline Euroscepticism Index 2016 & & & & & & & .389 & .174 & * & .060 & .076 & & .206 & .184 & & .020 & .080 & \\
\hline Anti-elitism Index 2018 & .709 & .284 & * & .636 & .131 & $* * *$ & .057 & .320 & & .126 & .146 & & .146 & .345 & & .183 & .152 & \\
\hline National Econ. Retr. ev. Diff. 2020-2016 & & & & & & & -.055 & .279 & & -.137 & .127 & & -.119 & .297 & & -.152 & .131 & \\
\hline Household Econ. Retr. ev. Diff. 2020-2016 & & & & & & & -.001 & .289 & & .140 & .133 & & -.014 & .300 & & 0.151 & .136 & \\
\hline Anti-Immigration Diff. 2020-2016 & & & & & & & .028 & .255 & & .784 & .140 & *** & -.157 & .267 & & .663 & .142 & $* * *$ \\
\hline Euroscepticism Diff. 2020-2016 & & & & & & & .368 & .193 & & .018 & .088 & & .300 & .194 & & .008 & .090 & \\
\hline Anti-elitism Index Diff. 2020-2018 & .857 & .289 & ** & .603 & .131 & $* * *$ & .160 & .312 & & .094 & .145 & & .190 & .340 & & .135 & .150 & \\
\hline L-R self-placement: Centre/Centre-Left/Left & & & & & & & & & & & & & -1.539 & 1.280 & & -.345 & .303 & \\
\hline L-R self-placement: Centre-Right & & & & & & & & & & & & & 1.120 & .835 & & 1.261 & .265 & *** \\
\hline L-R self-placement: Right & & & & & & & & & & & & & 2.505 & .729 & *** & 0.716 & .274 & ${ }^{* *}$ \\
\hline Ps eudo $\mathrm{R}^{2}$ & $\begin{array}{l}\text { Cox \& } \\
\text { Nagelke } \\
\text { McFadd }\end{array}$ & $\begin{array}{l}\text { Snell } .04 \\
\text { erke } .07 \\
\text { den } .049\end{array}$ & & & & & $\begin{array}{l}\text { Cox \& } \\
\text { Nagelk } \\
\text { McFad }\end{array}$ & $\begin{array}{l}\text { Snell .12 } \\
\text { terke .20 } \\
\text { den .14 }\end{array}$ & & & & & $\begin{array}{l}\text { Cox \& } \\
\text { Nagelk } \\
\text { McFad }\end{array}$ & $\begin{array}{l}\text { Snell } .17 \\
\text { kerke .28 } \\
\text { Iden } .210\end{array}$ & & & & \\
\hline
\end{tabular}

Note: Sig. indicates the level of significance; ${ }^{\star} \mathrm{p}<0.05$; $^{* *} \mathrm{p}<0.01$; ${ }^{* *} \mathrm{p}<0.001$.

Source: ITANES panel surveys 2016-2020 (n. cases 1412). 